\section{Kastamonu Eğitim Dergisi Kastamonu Education Journal}

Temmuz 2019 Cilt:27 Sayı:4

kefdergi.kastamonu.edu.tr
Başvuru Tarihi/Received: 26.08 .2018

Kabul Tarihi/Accepted: 30.10 .2018 DOI: $10.24106 /$ kefdergi.3304

\title{
Osmanlı Türkçesi Dersini Alan Öğrencilerin Yaptıkları Okuma, Yazma ve Gramer Hatalarının Sebepleri ve Sağaltılmaları Üzerine Bir Araştırma
}

\section{An Investigation on the Regulations and Responsibilities of Reading and Writing Failures Against Ottoman Turkish Language Students}

\section{Öz}

\author{
Mehrali CALP1
}

Bu çalışmada, Fen Edebiyat Fakültesi Türk Dili ve Edebiyatı Bölümü öğrencilerinin Osmanlı Türkçesi alanındaki okuma, yazma ve gramer bakımından yaptıkları hatalar ele alınmıştır. Çalışmanın amacı, öğrencilerin, Osmanlı Türkçesinde yaptığı okuma, yazma ve gramer hatalarının sebeplerini belirlemek ve elde edilen bulgular ışığında bu hataları sağaltmaya yönelik önerilerde bulunmaktır. Araştırma nitel bir çalışma olup veriler yarı yapılandırılmış görüşme formu yoluyla elde edilmiş ve içerik analizine tabi tutulmuştur. Bu amaçla 4 sorudan oluşan yarı yapılandırılmış bir görüşme formu hazırlanmıştr. Hazırlanan bu görüşme formu aracılığıyla dersi alan öğrenciler ile alan uzmanlarından görüş alınmıştır.

Araştırmada aşağıdaki sonuçlara ulaşılımıştır:

Osmanlı Türkçesi dersinde öğrencilerin en çok zorlandıkları durumlar: Arapça kelimelerin kalıplarını bilememe ve yazamama, metinleri okuyamama ve yazamama, dilbilgisinde yetersiz olma; 乌ै ( $\eta$ )lerin benzer seslerden ayırt edilememesi ve vokallerin yazımıdır.

Öğrenci hatalarının sebepleri: Arapça ve Farsça gramer bilgisinin yetersiz olması, yazımın (imla) çalışmasının yetersiz olması, Arapça, Farsça ve Osmanlıca kelimeleri ayırt edememe, yeterince metin okumama, yazma etkinliklerinin yapılmamasıdır.

Öğrencilerin karşılaştikları zorluklarla baş edebilmek için almayı düşündükleri önlemler: ders dışı tekrar ve alıştırma yapma, metin okuma ve yazma çalışmalarını artırmadır.

Öğrencilerin öğretimle ilgili faydalı olacağını düşündükleri önerileri: Derslerin alanında uzman olanlar tarafindan verilmesi, öğretim sürecinin kolaydan zora aşamalı olarak sürdürülmesi, haftalık yazma ödevi verilmesi, sık sık alıştırma yaptrılıması, çokça metin okunması şeklindedir.

Elde edilen bulgular ışı̆̆ında önerilerde bulunulmuştur.

Anahtar Kelimeler: dilbilgisi, okuma ve yazma hatası osmanlı türkçesi, yazım (imla).

\section{Abstract}

In this study, errors of reading, writing and grammar in the Ottoman Turkish area of the students of the Department of Turkish Language and Literature in the Faculty of Arts and Sciences were discussed.

The aim of the study is to determine the reasons for the mistakes in reading, writing and grammar that the students made in the Ottoman Turkish, and to make suggestions for the solution of these errors in the light of obtained findings. The study has been a qualitative study and the data were obtained through semi-structured interview form and subjected to content analysis. With this purpose, a semi-structured interview form consisting of 4 questions have been repaired. The students who took the course and the field experts were interviewed via this interview form.

The following results were obtained in the study: In Ottoman Turkish lectures the most difficult situations of students are: not knowing and writing the patterns of Arabic words, not reading and writing texts, insufficient grammar; 5) (n) cannot be distinguished from similar voices and writing vocals.

The reasons for student mistakes are: inadequate Arabic and Persian grammar knowledge, inadequate writing (spelling), inability to distinguish Arabic, Persian and Ottoman words, and not enough text reading and writing activities. Measures that students should take in order to cope with the difficulties encountered by students are: to re-learn extracurricular activities and improve their reading and writing skills. Suggestion that the students think that they will be useful for teaching: The lessons are given by experts in the field, the teaching process is carried out in from simple to difficult manner, weekly writing assignments, frequent exercises, and lots of text reading. Suggestions were made in the light of the obtained findings.

Keywords: grammar, ottoman turkish, reading and writing error, spelling. 


\section{Extended Summary}

Introduction: Ottoman Turkish is a language in which the Turks who lived in the borders of the Ottoman State spoke between the XIII. century and the XX. century. Ottoman Turkish, which uses Arabic letters in writing, is not a mixed language; it is a written language that covers a historical period of Turkish language which have different qualities both in terms of the language characteristics they carry and in terms of the use of the alphabet.

How to show the sounds in different alphabets used on a daily basis has been an important problem? Different uses in writing have been brought along spelling conflicts (Ülkütaş, 1991). As the researchers have pointed out, Arabic texts have had spelling problems since the early days of Arabic writing. The changes caused by the historical development conditions of Turkish language, on the one hand, the characteristics of the turn in which the text is imitated are intertwined and the problems they present, on the other hand, the differences between writing and phonology language has faced many challenges those who are interested in language and who are language users.

Purpose: The aim of the study is to determine the reasons of the mistakes related to reading, writing and grammar that the students made during the Ottoman Turkish lesson and the remedies of their being able to cope with these errors, and to make recommendations to the target group on ways to avoid/avoid these mistakes in the resulting findings.

Importance: At the end of the fourth semester of Ottoman Turkish lesson in the Department of Turkish Language and Literature of the Faculty of Arts and Sciences, determining the writing skills and the level reached by students participating the Turkish Language and Literature Program and whether they meet the standards are important in terms of the quality. And the reasons for not achieving the expected standards and how to manage with them are also important in terms of the quality of instruction. In this way, it is clear that it will be possible to make necessary repairs and corrections by receiving feedback about whether education is maintained in a healthy way.

Method: This study was a qualitative study and the data were obtained through a document review and subjected to content analysis. The method of this study, which is carried out in order to determine reading, writing and grammar mistakes of the students who attend the Turkish Language and Literature Program and the reasons of these mistakes that they have made about Ottoman Turkish at the end of 4 semesters; which is aimed to show the ways of avoiding these, is the survey (field research) study aiming to examine the events in natural conditions.

The Model of the Study: The survey model was used in the study.

Study Group: The study group of this research consists of second year students taking Ottoman Turkish lesson in Faculty of Arts and Sciences Department of Turkish Language and Literature, and teaching staff from Turkish Education Department, Turkish Language and Literature Department. The number of students who took Ottoman Turkish course is 142 , the number of teaching staff is 5 .

Data Collection Tool: In this study, document review and semi-structured interview form were used as a data collection method/tool.

Data Collection and Analysis : The data were analyzed through content analysis. Based on this model, a semi-structured interview form with four questions (Annexes 1 and 2) has been prepared to direct both to field specialists and to students who have taken courses. In the Ottoman Turkish lesson, the final form was formed by taking the opinions of the field experts in relation to the semi-structured interview form with 4 questions developed by the researcher to obtain data on the "reasons for the mistakes he made, the remedies to cope with these mistakes".

Findings: Findings are organized based on the order of the research questions. The answers given by the students to the research questions were discussed first, then the answers given by the lecturers to the research questions were discussed. Open-ended questions are kept constant in the order of questions, and each chapter is interpreted in itself.

Result and Discussion: When the findings are analyzed, it is seen that 4 basis points pay attention in terms of language characteristics of the classical Ottoman Turkish. These are: reading, writing, grammar and teaching process

Conclusions: Ottoman Turkish lesson is an area of knowledge and more skill area. The fact that Ottoman Turkish can be read and written correctly, beautifully and clearly depends on the intensive effort. Repetition and practice have an important place in this area, which is based on the coordination of muscle and brain power. It is important to check and guide from time to time whether the correct skills and habits to be earned are gained by the students.

Suggestions: An organic link between reading instruction and writing instruction should be established.

The reading and writing activity should always be carried out together; sentences and words that they learn to read to students should be printed at the same time.

Every reading, writing; every writing should follow the reading.

Writing activities should not have the capacity to bore students and to develop negative attitudes.

It is important to awaken students to desire beautiful writing.

It is important to take into account skills acquisition rather than providing students with a good writing experience.

The right skills and habits to be earned should be checked and guided from time to time whether the students have gained or not.

| Kastamonu Eğitim Dergisi, 27(4), 2019| 


\section{Giriş}

XIII. Yüzyılda Anadolu'da yükselmeye başlayan Osmanlı Devleti, diğer Türk yönetimleri arasında siyasi açıdan baskın duruma geçmeye başlayınca, halkın kullandığı dile de Osmanlı Türkçesi denilmeye başlanmışt. XIII. yüzyıl ile XX. yüzyıl arasında Osmanlı Devleti sınırları içinde yaşayan Türklerin konuşup yazdığı bu dil, Osmanlı Devleti'nin konuşlandığı geniş coğrafyadaki diğer diller, özellikle Arapça ve Farsça'dan çeşitli dil unsurlarını da bünyesine alarak gelişmesini sürdürmüştür. Yazıda Arap harflerini kullanan Osmanlı Türkçesi, karma bir dil, yapma bir dil değil: gerek alfabe kullanımı gerekse taşıdığı dil özellikleri bakımından farklı niteliklere sahip Türkçenin tarihî bir dönemini kapsayan bir yazı dilidir. Kültür ve medeniyet bakımdan temas halinde bulunduğu Arapça ve Farsça'dan çeşitli dil unsurlarını ödünç alması, dilbilimsel bakımından yadırganacak bir durum değildir Kaldı ki halkın kullandığı dil oldukça sade bir Türkçe olarak varlığını devam ettirmiştir.

Osmanlı Türkçesi, Türkiye Türkçesi'nin gelişme sürecinde Eski Anadolu Türkçesi diye adlandırılan ilk dönemi de içine alarak XIII. yüzyıldan XX. yüzyılın başlarına kadar devam eden yazı dilidir. "X. yüzyılda Türkler'in İslâmiyet'i kabul etmesiyle Türk devletleri, yavaş yavaş eski kültür sahalarından ayrılıp yeni bir kültür alanına girdiler. Böylece Türkçenin Eski Türkçe diye adlandırılan İslâmiyet'ten önceki dönemi kapanarak XI. yüzyıldan itibaren İslâm kültür ve medeniyeti altında gelişme gösteren yeni bir dönemi başladı." (Özkan, 2011).

Bu dönem, Faruk K. Timurtaş, Mecdut Mansuroğlu, Hasibe Mazıoğlu, Mustafa Özkan, Hayati Develi gibi birçok dil bilgini tarafindan Eski Türkiye Türkçesi dönemi olarak adlandırılmaktadır. "Türkiye Türkçesinin tarihi devresinin ilkini Eski Anadolu Türkçesi teşkil etmektedir. Selçuklu devri Türkçesini de içine alan bu devre XIII. asırdan XV. asrın sonuna kadar devam etmiştir. XV. asrın ikinci yarısı bir geçiş devri olmakla beraber, Eski Anadolu Türkçesinin hususiyetleri, bütün XVI. asır boyunca devam etmiş, hatta XVII. asırda da kendisini göstermiştir." (Timurtaş, 1995).

“Osmanlı Türkçesi'ni onun devamı olan bugünkü Türkçe'den ayrı düşünmek doğru değildir. Türkçe'nin değişik adlarla anılması, Türk milletinin dilinin uzun bir tarih içerisinde geniş bir coğrafyaya yayılarak çeşitli lehçelere ayrılmasından kaynaklanmıştrr. Osmanlı Türkçesi'nin diğer dillerden, özellikle Arapça ve Farsça'dan çok sayıda kelime alması, ihtiyaç duyduğu kavramları kendi kültüründe bulamayınca başka dillerden temin etmesi sonucudur. Bu yazı dilinde ortak i̇slam medeniyetine ait birtakım kelime ve terkipler kullanılmış, bunların birçoğu Türkçeleştirilmiş ve yeni anlamlar kazandırılmıştr." (Özkan, 2011).

Tarihî süreç içinde başlangıcından (Ana Türkçeden) günümüze kadar çeşitli aşamalardan geçen Türkçe farklı coğrafya ve topluluklarda ses, şekil ve anlatım bakımından birçok değişikliğe uğramıştı. Türkçe, kelime serveti bakımından da bu dinamizmini sürdürmüş; kullanıldığı coğrafyalarda konuşulan diğer dillerden de etkilenmiştir. Türkçe başka dillerden ödünç kelime almış ve o dillere kelime vermiş; bu arada birçok da alfabe değiştirmiştir. Eski Oğuz Türkçesi metinlerde ünlülerin yazııışıla ilgili olarak üzerinde durulması gereken husus zaman zaman Eski Uygur imlasını tesiriyle bütün ünlülerin gösterilmiş olması, bazı eserlerde de Arap-Fars imla geleneğinin tesiriyle kelimelerdeki bütün ünlülerin yazılmamasıdır. Buna bağlı olarak özellikle Türkçe kelimelerde yazım ve gramer sorunlarıyla karşı karşıya kalınmıştır.

Günümüze dek kullanılan farklı alfabelerde seslerin nasıl gösterileceği önemli bir problem olmuştur. Klasik Osmanlı Türkçesi döneminde Arapça ve Farsça kelimelerin yazımında aslına uygun yazım benimsenirken Türkçe kelimelerin yazımında kök ve eklerdeki ünlülerin gösterimine dayalı bir imlâ benimsenmiştir. Yazım hususundaki bu farklı kullanımlar imlâda karışıklıkları ve sorunları beraberinde getirmiştir. Bu karışıklık, Anadolu sahasında gelişen Türk yazı dilinde de devam eder. 13. yüzyıldan 19. yüzyıla kadar uzanan bu dönemi, dil yapısı ve imlâ sistemi bakımından 16. yüzyıla kadar ve sonrası olmak üzere iki farklı döneme ayırmak gerekir (Ülkütaşır, 1991). "13. yüzyıldan 15. yüzyılın ortasına kadar uzanan ilk dönemde, kurallı bir imlâ sistemi görülmemektedir. Bu döneme ait ilk yazılı metinlerde, genellikle Arapçanın imlâ kuralları hâkimdir. ... Karışıklık, Arapça ve Farsça kelimelerden ziyade Türkçe kelimelerde görülür. Eski Anadolu Türkçesi'nin başlarında daha çok hareke kullanılmış, daha sonra eklerde ve köklerde bir kalıplaşmaya gidilmiştir (Canpolat, 1981; aktaran: Üst, 2008, 672).

15. yüzyılın sonlarından itibaren ise, önce eklerde daha sonra da köklerde bir kalıplaşmaya gidilmiş; yazı diliyle konuşma dilinin birbirlerinden ayrılmasıyla da, Osmanlı imlâsı, çok defa telaffuzla bağlantısı bulunmayan klişeleşmiş bir imlâ durumuna gelmiştir.

Manzum eserlerde bu kalıplaşma biraz daha geç gerçekleşmiştir. Bunun sebebi, bu dönemde çok kullanılan imalelerdir. Aruza vakıf olan müstensihler, manzum eserlerde imale olan yerlerde, "hurûf-ı imlâ" $(1,9, \mathbf{g})$ kullanmışlardır. Hatta zihaflar sebebiyle, Arapça ve Farsça kelimelerin uzunluklarını göstermemişlerdir. Dolayısıyla bu dönemde, imlâ ile dilin fonetik yapısı arasında bir bağlantının göze çarptığı; yani yazı dili ile konuşma dili arasında bir paralelliğin görüldüğü ileri sürülmüştür (Korkmaz, 1995). 
Araştırmacıların işaret ettiği gibi, Arap harfli metinlerde, Arap yazı sisteminin kullanılmaya başlandığı ilk zamanlardan beri imlâ sorunları var olmuştur. Türkçenin tarihî gelişme şartlarından kaynaklanan değişmeler, bir yandan metnin istinsah edildiği döneme ait özelliklerin birbirine karışmış olması ve bunların ortaya koyduğu sorunlar, bir yandan da dilin yazı ve imlâsı ile fonolojisi arasındaki ayrılıklar dille ilgilenen ve kullananları birçok zorlukla karşı karşıya bırakmıştır.

19. yüzyıl itibarıyla da yazım problemleri dile getirilmiş, harflerin ıslahından, yeni bir alfabenin getirilmesinden bahsedilir hale gelinmiştir. Batıcılık anlayışının Abdullah Cevdet'ten sonra gelen başlıca isimleri Kılıçzâde Hakkı, Celâl Nuri (ileri) ve Ubeydullah Efgānî gibi düşünürler sosyal, siyasi, dini ve ahlaki birçok konu yanında dil ve alfabe üzerine görüşler beyan etmişlerdir. (Polat, 2000) Bu bağlamda Kılıçzade Hakkı'nın "Pek Uyanık Bir Uyku" adlı yazısı oldukça dikkat çekici görüşleri içermektedir. Ahmet Cevdet Paşa, Kavâid-i Osmanî adlı eserinde, Arap yazı geleneğinde gösterilmeyen seslerin belirtilmesinin gerekliliğini ifade etmiş ve bunun üzerine Encümen-i Dâniş'te de Arap harflerinin harekeli yazımı esası benimsenmiştir (Ertem, 1991).

Türkçenin tarihî süreç içerisinde geçirdiği değişik dönemlerde imla/yazım konuları sık sık gündeme gelmiş; özellikle Tanzimat döneminden başlayarak dil ve alfabe konuları tartışımış ve bu alanda önemli sayıda eser kaleme alınmıştır. Konuya ışık tutacak bir çalışma da Üst (2008) tarafindan yapılmıştı. "Bu meselenin çözümüne yönelik olarak da, en azından, imlâ ve gramer özelliklerini standartlaştırmayı sağlayacak eserler kaleme alınmıştır. 'Bir dilin sahip olduğu kelimeleri doğru yazmağa (imlâ) denilir.' İmlâyı bilmek kişinin kendi dilini yazıp okumasında temel şarttır. Kişi kendi dilinin imlâsına hâkim olmadığı zaman çeşitli karışıklıklara ve sorunlara yol açar: Bizim dilimiz Arapça, Farsça, Türkçe dillerinden mürekkeb olduğundan her kim olursa olsun dil kurallarına itibâr etmeyip de yazacağı kelimenin imlâsını kendi bildiği gibi yazmış olsa meselâ (ihtizâz), (ihzâr) kelimeleri gibi birçok şûretde yazılabilmesi mümkün ve bu ise okumak, yazmak hususunda pek çok güçlüğe yol açar." (Üst, 2008, 674).

19. yüzyılda imlâ sorununun çözümüne yönelik farklı görüşler ortaya atılmıştı. Arapça ve Farsça kelimeleri asılları ile yazmak, Türkçe kelimelerin yazımında bir standart oluşturmak gerektiği düşüncesi ileri sürülmüş; bu tartş̧malar 20. Yüzyılda da varlığını sürdürmüştür. Farklı boyut ve bakış açısıyla imla/yazım sorunu var olmaya devam etmektedir. Var olan bu sorunun, Osmanlı Türkçesi dersi kapsamında öğrencilere kazandırılmaya çalışılan okuma, yazma ve gramere ilişkin becerilerin öğretiminde de ortaya çıktı̆ı söylenebilir.

Dil bir iletişim aracı olma yanında kültür taşıyıcısıdır da. Kültürü koruyan ve yeni kuşaklara taşıyan bir dil olarak Osmanlı Türkçesi öğrencilerde imla (yazım) sorununa duyarlı olma, böylece Türkçe kelimelerin yazımında bir standarta ulaşma bilincini geliştirmede önemli bir işleve sahiptir. "Toplumsal hafizanın yaşatıması, ancak yazılı metinlerin bilinip anlaşılmasıyla, okumasıyla mümkün olabilir. Bizim eğitim politikalarımızda bu iş Edebiyat Fakültelerinin Türk Dili ve Edebiyat, Tarih, Sanat Tarihi, Bilgi ve Belge Yönetimi, Kütüphanecilik gibi bölümleriyle başka fakültelerin bu konularla ilgili bölümlerdeki eğitim-öğretim faaliyetleriyle yürütülmeye çalışılmakta, buralarda eğitilen gençler arasında yazılı kültür mirasını okuyup anlayabilecek uzmanların yetiştirilmesi hedeflenmektedir." (Develi, 2012, s.7).

Türk dilinin şekillenmesi sürecinde önemli zaman dilimlerinden birine karşılık gelen Osmanlı dönemi Türkçesinin genç kuşaklara öğretimi, Türk dilinin, tarihinin, kültürünün ve dünya görüşünün dünya sahnesindeki yerinin koruması bakımından önemlidir (Sevim ve Bayındır, 2016). Osmanlı Türkçesi dersi geçmişe açılan kapı için bir anahtar olarak düşünüldüğünde bu anahtarla açılacak kapıdan içeri giren nesil; yazı inkılâbının nedenlerini, Türk dilinin incelik ve zenginliğini, Türk sanatının ve sanatçısının estetik yaklaşımını, sanat anlayışını, Türk milletinin duyuş ve düşünüşünü, yaklaşık bin yıllık siyasi, sosyal, ekonomik, askerî ve kültürel yaşantısını, o döneme tanıklık eden eser ve belgelerden okuma, anlama imkânına sahip olacaktır (MEB, 2011).

Yapılan araştırmalarda, farklı düzey ve öğretim kurumlarında uygulanan Osmanlı Türkçesi Dersi Öğretim Programlarının kazanımlarının yeterince gerçekleşmediği yolunda yaygın bir kanaat bulunmaktadır. Bu durum, konunun araştırılmasını kaçınılmaz kılmaktadır (Çalışkan, 2013).

\section{Çalışmanın Önemi}

Türk Dili ve Edebiyatı Programına devam eden öğrencilerin 4. dönem sonunda Osmanlı Türkçesi dersinde ulaştikları düzey ve elde ettikleri yazma beceri ve alışkanlıklarının standartlara uygun olup olmadığının; beklenen standartlara ulaşılamamasının sebepleri ve nasıl sağaltılacağının belirlenmesi sürdürülecek öğretimin niteliği bakımından önemlidir. Bu yolla öğretimin sağııkı sürdürülüp sürdürülmediği hususunda geri bildirim alınarak gerekli onarım ve düzeltmelerin yapılmasının mümkün olacağı açıktır.

Bilindiği üzere Osmanlı Türkçesi dersi bir araç dersi olma yanında hedef kitleye dil, edebiyat, sanat, tarih ve sosyoloji alanlarda sunduğu malzeme dikkate alındığında öğrencileri bu ve benzeri alanlarda bilgilendirme ve olgunlaştirma 
gibi bir işleve de sahiptir. Türk Dili ve Edebiyat öğreniminde başarılı olmak, Osmanlı Türkçesinde edinilecek beceri ve alışkanlıkların niteliğine bağlıdır. Yeni Edebiyat, Eski Edebiyat ve Eski Anadolu Türkçesi ile ilgili metinleri okuma, anlama, yorumlama becerilerini geliştirmek, büyük ölçüde Osmanlı Türkçesi dersinde gramer, kelime bilgisi, kelimeleri uygun yerlerde kullanma ve sözlük(ler)den yararlanma gibi alanlarda elde edilecek beceri ve alışkanlıklarla doğrudan ilişkilidir. Hatta Tarihî Türk Lehçeleri yanında Türkiye Türkçesi ile ilgili temel kavram ve terimlerin içselleştirilip özümsenmesi de -büyük ölçüde- Osmanlı Türkçesinde edinilecek kazanımlara bağlıdır.

Tarihî süreç içinde Türkçe edebî dil olarak kullanılmaya başlamış ve bu dil ile giderek artan hız ve sayıda birçok eser meydana getirilmiştir. Osmanlı Türkçesi'yle sadece edebi eserler değil beş yüzyıllık tarih boyunca sosyal hayatın her alanına ait (edebiyat, tarih, tıp, hukuk, iktisat, tasavvuf, ahlak ve dinî ilimler vb.) binlerce eser telif edilmiştir. Osmanlı Türkçesi dersi, eski metinleri anlamak ve anlamlandırmak; bu eserlerdeki fikri, ilmi ve felsefi duyuş ve düşünüşü yeni kuşaklara ulaştırılmak bakımından büyük bir işleve sahiptir. Türkçenin devlet dili, bilim ve sanat dili olma özelliğini kazandığı, olgun edebi ürünlerini vermeye başladığı Osmanlı Türkçesi döneminin (13-20. yy) eserlerini tanımak, onları gün ışığına çıkararak Türk dilinin geçirdiği aşamaları bilmek dil bilinci bakımdan olduğu kadar Türkçenin inceliklerini keşfetme bakımından da önemlidir.

\section{Amaç}

Çalışmanın amacı, Osmanlı Türkçesi dersinde öğrencilerin yaptıkları okuma, yazma ve dilbilgisi ile ilgili hatalarının sebepleri ve bu hatalarla baş edebilmelerinin çarelerini belirlemek; elde edilen bulgular ışığında hedef kitleye bu hatalardan sakınma/sakındırma yolları hakkında önerilerde bulunmaktır.

Bu amaç doğrultusunda aşağıdaki sorulara cevap aranmıştır:

- Öğrencilere göre Osmanlı Türkçesi dersinde (okuma, yazma ve gramer) alanlarında en çok zorlandıkları durumlar nedir?

- Öğrencilere göre Osmanlı Türkçesi dersinde (okuma, yazma ve gramer) alanlarında içine düştükleri hataların sebepleri nelerdir?

- Öğrenciler, Osmanlı Türkçesi dersinde (okuma, yazma ve gramer) alanlarında karşılaşttkları zorluklarla baş edebilmek için neler yapmaktadırlar?

- Öğrencilerin Osmanlı Türkçesi dersinin (okuma, yazma ve gramer) alanlarının öğretimi ile ilgili kendilerine faydalı olacağını düşündükleri önerileri nelerdir?

- Öğretim üyelerine göre Osmanlı Türkçesi dersinde öğrencilerin (okuma, yazma ve gramer) alanlarında en çok zorlandıkları durumlar nedir?

- Öğretim üyelerine göre Osmanlı Türkçesi dersinde öğrencilerin (okuma, yazma ve gramer) alanlarında yaptıkları hataların sebepleri nelerdir?

- Öğretim üyelerine göre Osmanlı Türkçesi dersinde öğrenciler (okuma, yazma ve gramer) alanlarında en çok zorlandıkları durumlarla baş edebilmek için neler yapmaktadırlar?

- Öğretim üyelerinin Osmanlı Türkçesi dersinin (okuma, yazma ve gramer alanlarının) öğretimi ile ilgili öğrencilere faydalı olacağını düşündükleri önerileri nelerdir?

\section{Yöntem}

Bu araştırma nitel bir çalışma olup veriler doküman incelemesi yoluyla elde edilmiş ve içerik analizine tabi tutulmuştur. Türk Dili ve Edebiyatı Programına devam eden öğrencilerinin 4 dönem sonunda Osmanlı Türkçesi ile ilgili yaptıkları okuma, yazma ve dilbilgisi hatalarını ve bu hataların sebeplerini belirlemek; bunlardan sakınmanın yollarını göstermek amacıyla gerçekleştirilen bu çalışmanın yöntemi, olayları, olguları doğal koşulları içerisinde incelemeyi hedefleyen survey (alan araştırması) çalışmasıdır.

Araştırmada tarama modeli kullanılmıştr. Tarama modeli, var olan bir durumu var olduğu şekliyle betimlemeyi amaçlar. Araştırmaya konu olan olay, birey ya da nesne, kendi bağlamında ve olduğu gibi tanımlanmaya çalışıır. Onları, herhangi bir şekilde değiştirme, etkileme çabası gösterilmez. Önemli olan, bilinmek istenen şeyin gözlenip belirlenebilmesidir (Karasar, 2003).

\section{Çalışma Grubu}

Bu araştırmanın çalışma grubu, Osmanlı Türkçesi dersini alan Fen Edebiyat Fakültesi Türk Dili ve Edebiyat 2. sınıf öğrencileri ile bu dersi okutan Eğitim Fakültesi Türkçe Eğitimi Anabilim Dalı, Fen Edebiyat Fakültesi Türk Dili ve Edebiyatı Bölümleri öğretim üyelerinden oluşmaktadır. Osmanlı Türkçesi dersini alan öğrenci sayısı 142, öğretim üyelerinin sayısı $6^{\prime}$ dır.

Öğrencilerin 2. sınıflardan seçilmesindeki amaç, Fen Edebiyat Fakültesi Türk Dili ve Edebiyatı Bölümlerinde dört dö- 
nem olarak okutulan Osmanlı Türkçesi dersinin dört döneminin de alınmış olmasını sağlamaktır. Bu yolla öğrencilerin okuma, yazma ve dilbilgisi bakımlarından Osmanlıcada ulaştıkları en son düzey görülmeye çalışılmıştır.

\section{Verilerin Toplanması ve Analizi}

Bu araştırmada veri toplama yöntemi/aracı olarak doküman incelemesi ile yarı yapılandırılmış görüşme formu kullanılmıştır. "Doküman incelemesi, araştırılması hedeflenen olgu veya olaylar hakkında bilgi içeren yazılı materyallerin analizini kapsar. Nitel araştırmalarda doküman incelemesi tek başına bir veri toplama yöntemi olarak kullanılabilir. Hangi dokümanların önemli olduğu ve veri kaynağı olarak kullanılabileceği araştırma problemi ile yakından ilgilidir" (Yıldırım, A. ve Şimşek, H. 2011: 188).

Osmanlı Türkçesi dersinde öğrencilerin "yaptığı hataların sebepleri, bu hatalarla baş edebilmenin çareleri" hakkında veri elde etmek üzere araştırmacı önce 4. dönem sonunda yapılan final sınavındaki öğrenci kâğıtları, doküman analizine tabi tutulmuştur. Analize tabi tutulan sınav kâğıtları yazı yönü ve harfler arasında bağlant kurma (bitişip bitişmeme), imla kurallarına uygunluk (Türkçe, Arapça ve Farsça yazım kurallarına uyup uymama) bakımlarından değerlendirilmiştir.

Osmanlı Türkçesinin Türkçe, Arapça ve Farsçadan oluşan kelime ve kelime gruplarının imlâ ve gramer özellikleri bakımından öğrencilerin yanlış kullanımları belirlenmiştir. Öğrencilerin yaptıkları hatalar okuma, yazma ve dilbilgisi ile sınırlı tutulmuş; dinleme konuşma gibi dil becerileri kapsam dışında tutulmuştur. Öğrencilerin final sınavındaki sorulara vermiş oldukları cevaplar değerlendirilerek yaptıkları tipik hatalar belirlenmiştir. Bu hatalar 14 başlık halinde kategorize edilmiş; her bir kategori için yeteri kadar örnek gösterilmiştir.

Oluşturulan bu örnekçeye? dayalı olarak gerek alan uzmanlarına gerekse dersi alan öğrencilere yöneltmek üzere 4 sorulu yarı yapılandırılmış görüşme formu (Ek: 1,2) hazırlanmıştır. Osmanlı Türkçesi dersinde öğrencilerin "yaptığı hataların sebepleri, bu hatalarla baş edebilmenin çareleri" hakkında veri elde etmek üzere araştırmacı tarafindan geliştirilmiş 4 sorulu yarı yapılandırılmış görüşme formu ile ilgili olarak alan uzmanlarından görüş alınarak son şekli oluşturulmuştur. Hazırlanan bu görüşme formuyla dersi alan öğrenciler ve alan uzmanlarından görüş alınmıştır. Veriler, içerik analizi yoluyla çözümlenmiştir.

Yarı yapılandırılmış görüşme formu aşağıdaki açık uçlu soruları kapsamaktadır.

- Osmanlı Türkçesi dersinde en çok zorlandığınız husus nedir?

- Bu hata/ları niçin yaptı̆̆ınızı düşünüyorsunuz?

- Karşılaştı̆ınız zorluklarla baş edebilmek için neler yapıyorsunuz?

- Öğretimle ilgili size faydalı olacağını düşündüğünüz önerileriniz nelerdir?

\section{Bulgular}

Bu bölümde elde edilen bulgular araştırma sorularının sırasına göre düzenlenmiştir. Önce öğrencilerin sonra öğretim üyelerinin araştırma sorularına verdikleri cevaplar ele alınmıştır. Açık uçlu sorular soruların sırası sabit tutulmuş her bölüm kendi içinde yorumlanmıştır.

\section{Öğrencilerin Araştırma Sorularına Verdikleri Cevaplar}

\section{Tablo: 1. Öğrencilere göre Osmanlı Türkçesi dersinde en çok zorlanılan durumlar}

\begin{tabular}{|c|c|c|c|}
\hline Temalar & I. Osmanlı Türkçesi dersinde en çok zorlandığınız husus nedir? & Sıklık & $\begin{array}{l}\text { Bölüm } \\
\text { Sıklığı }\end{array}$ \\
\hline $\begin{array}{l}\text { 1. İsteksiz Olma / Amoti- } \\
\text { vasyon }\end{array}$ & Derse karşı isteksiz olma gerekli görmeme. & 1 & 1 \\
\hline \multirow{10}{*}{$\begin{array}{l}\text { 2. Arapça ve Farsça keli- } \\
\text { meleri Okuma ve Yazma }\end{array}$} & Arapça kelimelerin kalıplarını bilme ve yazmada zorlanma & 17 & \multirow{10}{*}{38} \\
\hline & Arapça kelimelerin kalıplarında sıkıntı yaşama & 2 & \\
\hline & Arapça ve Farsça kelimelerinde yazma da zorluk çekme & 2 & \\
\hline & Arapça, Farsça tamlamaları algılayamama & 4 & \\
\hline & Arapça, Farsça ve Türkçe kelimelerin kökenini belirleyememe & 5 & \\
\hline & Arapça ve Farsça kelimeleri okuma ve yazmada zorlanma & 1 & \\
\hline & Farsça kelimelerde zorluk çekme & 1 & \\
\hline & Kelimelerin imlası ile ilgili bilgileri ayırt etmede zorlanma & 3 & \\
\hline & Kelimelerin yazımında ünlü ve ünsüz eklerin kullanımında zorlanma & 2 & \\
\hline & Harfleri birleştirmede sıkınt yaşama & 1 & \\
\hline
\end{tabular}

| Kastamonu Eğitim Dergisi, 27(4), 2019| 


\begin{tabular}{|c|c|c|c|}
\hline Temalar & I. Osmanlı Türkçesi dersinde en çok zorlandığınız husus nedir? & Sıklık & $\begin{array}{l}\text { Bölüm } \\
\text { Sıklığı }\end{array}$ \\
\hline 3. Ödev & Fazla ödev verilmesi karşısında bıkkınlık gösterme & 2 & 2 \\
\hline 4. Öğretim & Öğretimin nitelik bakımında yeterli olmaması & 1 & 1 \\
\hline \multirow{2}{*}{$\begin{array}{l}\text { 5. Metinleri Okumada } \\
\text { Zorluk Çekme }\end{array}$} & Osmanlıca yazıları okuma ve yazmada zorlanma & 10 & \multirow{2}{*}{14} \\
\hline & Metin okumada zorluk çekme. & 4 & \\
\hline \multirow{7}{*}{$\begin{array}{l}\text { 6. Arabi Harf Sistemi- } \\
\text { nin Latin Yazı Sistemin- } \\
\text { den Farklı olması }\end{array}$} & Yazmada zorluk çekme & 28 & \multirow{7}{*}{51} \\
\hline & Yazmada dilbilgisi olarak eksik olma, zorluk çekme & 7 & \\
\hline & Osmanlıca bazı harflerin farklı sesleri karşılaması, ayırt edilememesi & 4 & \\
\hline & Kelimelerde ünlülerin yazılıp yazılmayacağını kestirememe & 3 & \\
\hline & $\begin{array}{l}\text { Osmanlıca da harflerin başta, ortada ve sonunda yazılımlarını } \\
\text { karıştırma }\end{array}$ & 4 & \\
\hline & Yazma hususundaki kuralların iyi bilinmemesi & 4 & \\
\hline & Arapça ve Farsça kelimelerin Türkçe kelimelerden çok olması & 1 & \\
\hline $\begin{array}{l}\text { 7. Osmanlıca Yazı Türü/ } \\
\text { Fondu }\end{array}$ & Osmanlıca yazı türlerinin okunmasında zorluk çekme & 6 & 6 \\
\hline \multirow{2}{*}{$\begin{array}{l}\text { 8. Ince ve Kalın Harfleri } \\
\text { Ayırt Edememe }\end{array}$} & $\begin{array}{l}\text { Yazıda birden çok ses değeri olan harfleri (homograph/ homophone) ayırt } \\
\text { edememe }\end{array}$ & 4 & \multirow{2}{*}{8} \\
\hline & Harflerden ince ve kalın harfleri ayırt edememe & 4 & \\
\hline $\begin{array}{l}\text { 9. Dilbilgisinde Yetersiz } \\
\text { Olma }\end{array}$ & Dilbilgisi ve yazmada yetersiz olma, zorluk çekme & 14 & 14 \\
\hline Toplam & & 135 & 135 \\
\hline
\end{tabular}

Tablo: 1'de öğrencilerin Osmanlı Türkçesi dersinde en çok zorlandıkları durumlar yer almaktadır. Tablo incelendiğinde 9 tema altında toplam 135 alt tema bulunmaktadır. Bunlardan en fazla "Arabi harf sisteminin Latin yazı sisteminden farklı olması" başlıklı 6. tema olup 51 sıklığa sahiptir. Bu temanın genel karakteristiği "yazma becerisi" ile ilgili olmasıdır. Nitekim "Arapça ve Farsça kelimeleri okuma ve yazma" başlıklı 2. tema da içerik bakımından kelime ölçeğinde "okuma ve yazma"yı kapsamaktadır. Yoğunluk bakımından bunları 14 (ondörder) sıklıkla "metinleri okumada zorluk çekme" başıkı 5. ve "dilbilgisinde yetersiz olma" başlıklı 9. Tema gelmektedir.

Tek tek alt tema bazında "Arapça kelimelerin kalıplarını bilme ve yazmada zorlanma" (17), "Osmanlıca yazıları okuma ve yazmada zorlanma" (10), "yazmada zorluk çekme" (28), "dilbilgisi ve yazmada yetersiz olma, zorluk çekme" (14) kez vurgulanmıştr.

\section{Tablo: 2. Öğrencilerin hatalarının sebepleri hakkındaki görüşleri}

\section{Temalar}

2. İlgi Azlığı/İsteksizlik
1. Ön Bilgi Eksikliği

\section{Belirtilen hata veya hataları niçin yaptığınızı düşünüyorsunuz?}

Dilbilgisi ve yazmada yetersiz olma, zorluk çekme.

Ön bilgiye sahip olmama, hazırbulunuşluk bakımından yetersiz olma

Derse yeteri kadar ilgi ve sempati duymama

Dersi gerekli görmeme

\section{Sıklık Bölüm Sıklığı}

18

Yeterince okuma, yazma etkinliklerinin (alıştırmaların) yapılmaması 34

4. Derse Yeterli Zaman Ayırmama

Derse yeteri kadar vakit ayırmama

Düzenli ders çalışma alışkanlığına sahip olmama

5. Derse Yönelik Tutum

Osmanlı Türkçesi Dersine önyargılı yaklaşma

Uygulamaya yeteri kadar ağırlık verilmemesi

Dersin işleniş süresinin yeterli olmaması

7. Dilbilgisi
Osmanlı Türkçesi gramer bilgisinin eksiklik olması

Osmanlıcada yazma kurallarının bilinmemesinden kaynaklı hatalar
16

1

$4 \quad 4$

5

34

9

34

42

3

2

1

8

3 


\begin{tabular}{|c|c|c|c|}
\hline Temalar & 2. Belirtilen hata veya hataları niçin yaptığınızı düşünüyorsunuz? & Sıklık & Bölüm Sıklığı \\
\hline 8. Geri Bildirim Alamama & Eksikliklerin üzerinde durmama & 1 & 1 \\
\hline \multirow{4}{*}{ 9.Harflerin Kavranamaması } & İnce ve kalın harfleri ayırt edememe & 2 & \multirow{4}{*}{11} \\
\hline & Harfleri yeteri kadar tekrar edilmemesi, çabuk unutulması & 3 & \\
\hline & $\begin{array}{c}\text { Osmanlı Türkçesinde harflerin başta, ortada ve sonda yazımlarını } \\
\text { karıştırma }\end{array}$ & 4 & \\
\hline & Arap harfleri ile Latin harflerinin farklı sistemlere sahip olması & 2 & \\
\hline \multirow{2}{*}{$\begin{array}{l}\text { 10. Öğretim Elamanının tutu- } \\
\text { mu }\end{array}$} & Hocanın tutumuna bağlı olarak derse isteksiz davranma & 1 & \multirow{2}{*}{2} \\
\hline & Hocanın ders konularını hızlı işlenmesi & 1 & \\
\hline \multirow{3}{*}{$\begin{array}{l}\text { 11. Arapça, Farsça Kelimelerin } \\
\text { Yapı ve Anlamlarını Ayırt Ede- } \\
\text { meme }\end{array}$} & Arapça, Farsça ve Osmanlıca kelimeleri tanıyamama, ayırt edememe & 15 & \multirow{3}{*}{20} \\
\hline & Arapça ve farsça tamlamaların anlaşılmaması & 3 & \\
\hline & Kelimelerin kökeni bilmeme ve çeviride kelimelere dikkat etmeme & 2 & \\
\hline \multirow{3}{*}{$\begin{array}{l}\text { 12.Okuma Alışkanlığının Ol- } \\
\text { maması }\end{array}$} & Okuma-yazma alıştırmalarının yeterince yapılmaması & 4 & \multirow{3}{*}{7} \\
\hline & Osmanlı Türkçesi Dersine önyargılı yaklaşma & 2 & \\
\hline & Osmanlı Türkçesi dersinin geç saatlere konulması & 1 & \\
\hline \multirow{3}{*}{ 13. Öğretimi Yeterli Bulmama } & Öğreticilik bakımında öğretimin yeterli olmaması & 13 & \multirow{3}{*}{15} \\
\hline & Öğrenci düzeyinin dikkate alınmaması & 1 & \\
\hline & Osmanlı Türkçesi dersinin geç saatlere konulması & 1 & \\
\hline \multirow{4}{*}{$\begin{array}{l}\text { 14. Yazma Kurallarının Bilin- } \\
\text { memesi }\end{array}$} & Yazmada zorluk çekme & 8 & \multirow{4}{*}{13} \\
\hline & Osmanlı Türkçesinin imla kurallarının farklı olması & 3 & \\
\hline & Osmanlı Türkçesi harf sisteminin Latin yazı sisteminden farklı olması & 1 & \\
\hline & Yazı yazma yeteneğinin olmaması & 1 & \\
\hline Toplam & & 173 & 173 \\
\hline
\end{tabular}

Tablo: 2'de Öğrencilerin hatalarının sebepleri hakkındaki görüşleri yer almaktadır. Tablo incelendiğinde 14 tema altında toplam 173 alt tema bulunmaktadır. Bunlardan en fazla "derse yeterli zaman ayırmama" başlıklı 4. tema olup 42 sıklığa sahiptir. Bu temanın genel karakteristiği "düzenli ders çalışma alışkanlığına sahip olunmaması"dır. Yoğunluk bakımından bunları 34 (otuzdört) sıklıkla "ön bilgi eksikliği" başlıklı 1. Tema izlemektedir.

Tek tek alt tema bazında sebepler "Osmanlı Türkçesi dersi için ilk sınıfta yeteri bilgi ve beceri elde edememe" (18), "Ön bilgiye sahip olmama, hazırbulunuşluk bakımından yetersiz olma" (16), "yeterince okuma, yazma etkinliklerinin (alıştırmaların) yapılmaması" (34), "Arapça, Farsça ve Osmanlıca kelimeleri tanıyamama, ayırt edememe" (15), "öğreticilik bakımında öğretimin yeterli olmaması" (13) kez vurgulanmıştır.

Tablo: 3. Öğrencilerin karşılaştkları zorluklarla baş edebilmek için aldıkları/almayı düşündükleri çareler/önlemler

\begin{tabular}{|c|c|c|c|}
\hline Temalar & 3. Bu zorlukla baş edebilmek için neler yapıyorsunuz? & Sıklık & Bölüm Sıklığı \\
\hline \multirow{3}{*}{ 1. Akran Desteği Alma } & Akran desteği alma & 2 & \multirow{3}{*}{4} \\
\hline & Alanında uzman kişilerden ders alma & 1 & \\
\hline & Dönüt alarak karşılaşılan sorunları aşma & 1 & \\
\hline \multirow{2}{*}{$\begin{array}{l}\text { 2. Bireysel Olarak Öğrenmeye } \\
\text { Çalışma }\end{array}$} & Osmanlıca metinleri Arap harfleriyle yazmaya ağırlık verme & 1 & \multirow{2}{*}{4} \\
\hline & Eksiklikler üzerinde durarak bireysel olarak öğrenmeye çalışma & 3 & \\
\hline 3. Alıştırmalar Yapma & Arapça, Farsça kelimeler, tamlamalar üzerinde çalışmalar yapma & 5 & 5 \\
\hline \multirow{5}{*}{$\begin{array}{l}\text { 4. Öğrenilenleri Tekrarlama ve } \\
\text { alıştırma yapma }\end{array}$} & Ders dışı tekrar ve alıştırma yapma & 31 & \multirow{5}{*}{47} \\
\hline & Öğrenilenleri tekrar edip uygulama çalışmaları yapma & 8 & \\
\hline & Temel kurallar üzerinde çalışmalar yapma & 3 & \\
\hline & Yazma alıştırmaları yaparak (karşılaştırma) zorlukları aşma & 4 & \\
\hline & Günü gününe konuları tekrar etme & 1 & \\
\hline
\end{tabular}




\section{Temalar}

5. Dilbilgisi Gramer Konularına Ağırlık

6. Elektronik Ortamdaki Metinlerden Yararlanma

Elektronik ortamdaki metinlerden yararlanma (Video, telefona sözlük vb. materyallerden destek alma)

Sözlük vb. materyallere başvurma

Kaynak kitaplardan faydalanma

Ders kitabından kurallara çalışma

7. Kaynak Kitaplardan Faydalan-

$\mathrm{ma}$

8. Kelimelerin Ait Olduğu Dili Öğrenme

Kelimelerin Türkçe ya da Arapça olup olmadığını öğrenme

Özel olarak Arapça ve Osmanlıca kursuna gitme, destek alma

Metin okuma ve yazma çalışmaları yapma

Metin çevirileri yapma

10. Metin Okuma ve Yazma ÇaIışmaları

11. Ödevleri Yapma

Olabildiğince çok metinle yüz yüze gelme ve eleştirel okuma

Kelimelerin herhangi bir kaynağa bakmadan ezberden yazma

Ödevleri yapma.

Öğrenci çalışmasını olumlulama

Rehber desteği almaya çalışma

Ön yargıları kırmaya çalışarak zorlukların üstesinden gelme

Tablo: 3’te Öğrencilerin karşılaştıkları zorluklarla baş edebilmek için aldıkları/almayı düşündükleri çareler yer almaktadır. Tablo incelendiğinde 13 tema altında toplam 126 alt tema bulunmaktadır. Bunlardan en fazla "öğrenilenleri tekrarlama ve alıştırma yapma" başlıklı 4. tema olup 47 sıklığa sahiptir. Bu temanın genel karakteristiği "tekrarlama ve alıştırma yapmak"tır. Yoğunluk bakımından bunları 29 (yirmidokuz) sıklıkla “metin okuma ve yazma çalışmaları” başlıklı 10. tema izlemektedir.

Tek tek alt tema bazında "ders dışı tekrar ve alıştırma yapma” (31), "öğrenilenleri tekrar edip uygulama çalışmaları yapma" (8), "kelimelerin Türkçe ya da Arapça olup olmadığını öğrenme" (8), "metin okuma ve yazma çalışmaları yapma" (21) kez vurgulanmıştır.

Tablo: 4. Öğretimle ilgili size (öğrenciler) faydalı olacağını düşündüğünüz önerileriniz nelerdir?

\begin{tabular}{|c|c|c|c|}
\hline Temalar & $\begin{array}{c}\text { Öğretimle ilgili size (öğrenciler) faydalı olacağını düşündüğünüz } \\
\text { önerileriniz nelerdir? }\end{array}$ & Sıklık & $\begin{array}{l}\text { Bölüm } \\
\text { sıklığı }\end{array}$ \\
\hline 1. Akran Desteği Alınması & Akran desteği alınmalı & 1 & 1 \\
\hline \multirow{3}{*}{ 2. Alıştırma, Tekrar yapma } & Sınıfta uygulama yaptırılıp eksikler belirlenmeli & 7 & \multirow{3}{*}{10} \\
\hline & Anlatım sıklaştırılmalı ve düzenli tekrar yapılmalı & 2 & \\
\hline & Alıştırmaların sık sık yapılmasıyla öğretimin verimi artırılmalı & 1 & \\
\hline \multirow{2}{*}{$\begin{array}{l}\text { 3. Bireysel Olarak Çaba } \\
\text { Gösterme }\end{array}$} & Farklı kaynaklardan yararlanmalı & 2 & \multirow{2}{*}{3} \\
\hline & Bireysel olarak çaba gösterilmeli & 1 & \\
\hline \multirow{3}{*}{$\begin{array}{l}\text { 4. Dersi Öğrenciye Sevdir- } \\
\text { me, Benimsetme }\end{array}$} & Ders öğrenciye sevdirilmeli & 6 & \multirow{3}{*}{9} \\
\hline & Derste öğrenci düzeyine uygun (kolay) metinler işlenmeli & 2 & \\
\hline & Ders ana (temel) ders olarak okutulmalı & 1 & \\
\hline \multirow{4}{*}{ 5. Ek Ders Alma } & Ek ders verilmeli, sözlük çalışmaları yapmalı & 4 & \multirow{4}{*}{11} \\
\hline & Yeterli düzeyde ek okuma çalışmaları yapılmalı & 3 & \\
\hline & Eski metinlerin incelenmesi ile öğretimin kalitesi artırılmalı & 2 & \\
\hline & Etkinliklere çokça yer verilmeli, ders saatleri artırılmalı & 2 & \\
\hline
\end{tabular}




\begin{tabular}{|c|c|c|c|}
\hline Temalar & $\begin{array}{c}\text { Öğretimle ilgili size (öğrenciler) faydalı olacağını düşündüğünüz } \\
\text { önerileriniz nelerdir? }\end{array}$ & Sıklık & $\begin{array}{l}\text { Bölüm } \\
\text { sıklığı }\end{array}$ \\
\hline \multirow{5}{*}{$\begin{array}{l}\text { 6. Hocaların Yeterlilikleri ve } \\
\text { Derse Karşı Tutumları }\end{array}$} & Dersler alanında uzman olanlar tarafindan verilmeli & 18 & \multirow{5}{*}{33} \\
\hline & Konular tam olarak öğretilmeden sonraki konuya geçilmemeli & 7 & \\
\hline & Kelimelerin yapısı tam ve doğru olarak öğretilmeli & 4 & \\
\hline & Hocalar ölçme ve değerlendirmede objektif davranmalı & 2 & \\
\hline & Hocalar dersi etkin ve verimli anlatmalı & 2 & \\
\hline \multirow{6}{*}{$\begin{array}{l}\text { 7. Okuma ve Yazma Çalış- } \\
\text { malarına Önem Verme }\end{array}$} & Okuma ve yazma çalışmalarına ek ödev ve alıştırmalar verilmeli & 2 & \multirow{6}{*}{12} \\
\hline & Okuma ve yazma çalışmalarına önem verilmeli & 4 & \\
\hline & Osmanlıca alfabesi üzerinde durulmalı ve öğrenciye kavratılmalı. & 2 & \\
\hline & Osmanlı Türkçesine ayrılan süre yeterli olmalı & 2 & \\
\hline & Osmanlı Türkçesinin edebiyatın temeli olduğu fark edilmeli & 1 & \\
\hline & Metin incelemeleri yapılmalı & 1 & \\
\hline 8. Kurslardan Yararlanma & Kurslardan yararlanılmalı & 1 & 1 \\
\hline \multirow{4}{*}{ 9. Ödev Verme } & Ödev verilerek konunun pekiştirilmesi sağlanmalı & 7 & \multirow{4}{*}{12} \\
\hline & Okuma ve yazma çalışmaları dışında ödev ve alıştırmalar yeterli olmalı & 2 & \\
\hline & Ödevler çok verilmemeli & 2 & \\
\hline & Ödevler günü gününe izlenmeli kontrol edilmeli & 1 & \\
\hline \multirow{8}{*}{$\begin{array}{l}\text { 10. Öğretim ve Öğrenim } \\
\text { Süreci }\end{array}$} & Öğretim süreci kolaydan zora aşamalı olarak sürdürülmeli & 17 & \multirow{8}{*}{50} \\
\hline & Derslerde öğrenciler etkin konuma getirilmeli & 7 & \\
\hline & Öğrencilerin öğrenme düzeyleri arasındaki fark gözetilmeli & 6 & \\
\hline & Öğretim kalitesi artırılmalı & 4 & \\
\hline & Birinci sınıfta temel bilgi ve beceriler kazandırılmalı & 4 & \\
\hline & Öğrenmede uygulamalara daha çok zaman ayrılmalı & 6 & \\
\hline & Öğrenciler usandırılmamalı & 3 & \\
\hline & Zihni çaba gerektiren dil dersleri erken saatlere konulmalı & 3 & \\
\hline \multirow{2}{*}{ 11. Rehberlik Yapılması } & Rehberlik hizmeti alınmalı & 12 & \multirow{2}{*}{17} \\
\hline & Öğretmen öğrenci ile ilgilenmeli, hoş görülü olmalı & 5 & \\
\hline Toplam & & 159 & 159 \\
\hline
\end{tabular}

Tablo: 4'te Öğrencilerin öğretimle ilgili kendilerine faydalı olacağını düşündükleri önerileri yer almaktadır. Tablo incelendiğinde 11 tema altında toplam 159 alt tema bulunmaktadır. Bunlardan en fazla "Öğretim ve Öğrenim Süreci" başlıklı 10. tema olup 50 sıklığa sahiptir. Bu temanın genel karakteristiği "öğretim sürecinin kolaydan zora aşamalı olarak düzenlenmesini" öngörmesidir. Yoğunluk bakımından bunları 33 (otuzüç) sıklıkla "Hocaların Yeterlilikleri ve Derse Karşı Tutumları" başlıklı 6. tema izlemektedir. Tek tek alt tema bazında "dersler alanında uzman olanlar tarafindan verilmeli" (18), "öğretim süreci kolaydan zora aşamalı olarak sürdürülmeli" (17), "rehberlik hizmeti alınmalı" (12) "sınıfta uygulama yaptırılıp eksikler belirlenmeli" (7), "konular tam olarak öğretilmeden sonraki konuya geçilmemeli" (7), "ödev verilerek konunun pekiştirilmesi sağlanmalı" (7), "derslerde öğrenciler etkin konuma getirilmeli" (6) kez vurgulanmıştır.

\section{B. Araştırma Sorularına Öğretim Üyelerinin Verdikleri Cevaplar}


Tablo 5. Öğretim Üyelerinin Osmanlı Türkçesi dersinde öğrencilerin en çok zorlandıkları durumlar hakkındaki görüşleri

\section{Soru}

Öğretim Elemanı

\section{Osmanlı Türkçesi dersinde öğrencilerin en çok zorlandıkları husus/lar nelerdir?}

3) : ๆ lerin kullanımı. Bu sesin bulunduğu kelime ve ilgi eki, ikinci şahıs eklerinin bilgisel olarak da yeterince

A..Y..... bilinmemesi

M.... T....

Ödev yapmaya razı olmama

3) : ๆ lerin kullanımı. Bu sesin tam olarak bilinmemesi

Vokallerin yazımı

B... B.... Kalıpların anlama ve işleve olan katkısı

Ödev yapmama

Kelimelerin Türkçe mi, Arapça mı yoksa Farsça mı olduğunu kavratabilmek. Bu özellikle önemli. Çünkü Arapça

F.... T..... ve Farsça kelimeleri Türkçe kelimelerin yazımında uyulması gereken kurallara göre değil, orijinal halleriyle yazmak gerekiyor. Bunu yapabilmek de en nihayet Arapça ve Farsça kelimeleri doğru bir şekilde ayırt edebilmeye ve kelimenin orijinal halini bilmeye bağı.

Kendinden sonra gelen harflerle bitişmeyen harfleri ayırt etmek

Bitişmeyen harfleri, kendinden önce gelenlerle de bitiştirmemek

i............ Yeni alfabede kullanmadığımız Arap fonetiğine has harflerin yazımı

Ince ve kalın harflerin kullanımlarını ayırt edememe. (Örnek: kaf ile kef harflerinin nerelerde kullanılacağını bilememe)

Arapça kelimelerdeki ünlülerin yazımı. Zira öğrenci kelimenin Arapça mı yoksa Türkçe mi olduğunu bilmiyor.

Bugün dilimizde aynı sesin karşılığı olarak kullanılan tek harf varken, Osmanlıcada her ses için birkaç harf var. Örneğin öğrenci "z, s" gibi birden çok harfle karşılanan sesleri ayırt edemiyor.

Kelime başındaki “ayn” ciddi bir problem. Çoğu defa elif’le yazılıyor.

H.... K....

Nazal n sesi için kullandığımız sağır kef yerine çoğu defa "nun" harfinin tercih edilmesi.

Birleşmemesi gereken harfler, ünlülerin yazımı.

Ses-harf ayrımı.

Arapça kelimelerin imlası.

İmlanın henüz tam olarak oturmadığı 13 ve 14. Yüzyıl metinlerindeki uygulamalar.

Tablo: 5'te öğretim elemanlarının Osmanlı Türkçesi dersinde öğrencilerin en çok zorlandıkları durumlar hakkındaki görüşleri yer almaktadır. Tablo incelendiğinde öğretim elemanlarının konuyla ilgili toplam 19 iteme (maddeye) işaret ettikleri, bunlardan birkaçına farklı öğretim elemanlarınca ortaklaşa dikkat çektikleri görülmektedir. Bunlar: (1) 歺: / $/ \mathrm{g}$ lerin kullanımı, (2) vokallerin (ünlülerin) yazımı, (3) Arapça kelimelerin kalıplarının anlama ve işleve olan katkısı, (4) Sesharf- kelime ilişkisi, (5) İnce ve kalın harflerin kullanımı (Örnek: kaf ile kef gibi), (6) fonetik ayrım yapamama, (7) bitişen ve bitişmeyen harfleri ayırt edememe, (8) ders çalışma (ödev/alıştırma yapma)ya karşı isteksizlik, (9) Arap fonetiğine has harflerin yazımı, (10) kelimelerin Türkçe mi, Arapça mı yoksa Farsça mı olduğunu kavrayamamalarıdır. 


\section{Tablo 6. Öğretim Üyelerinin hataların sebepleri hakkındaki görüşleri}
6. Soru
Öğretim Elemanı

\section{6. Örnekleri gösterilen hataların niçin yapıldığını düşünüyorsunuz?}
Transkript işaretlerini en başta öğretmeme ve sürekli kullanmama.
A..Y..... Türk Dili kaynaklı kelimelerin imlası öğretilirken ünlülerin yazımı üzerinde aşırı durma olabilir.
Yeterince imla çalışması yapılmaması olabilir.
Arapça ve Farsça gramer bilgisinin yetersiz olması
M.... T....
Yazımın (imla) çalışmasının yetersiz olması
Not: Yeni bir dil, yeni bir lehçe, yeni bir dönem veya yeni bir alfabe kullanımı öğrenimi bilgi öğrenmenin çok ötesinde alışkanlık işidir. Dolayısıyla öğreniciye ne kadar çok alıştırma/ödev yaptırılırsa hatalar o kadar azalır. Derse karşı öğrencilerin güdülenmişlik düzeyleri düşüktür. Öğrenciler, edindiği bilgilerin kullanılması noktasında heveslendirilmeli, dönemin başında öğrencilere "Dönem sonu hedefleri" bildirilmelidir. Ders sürecinde kuralların gerçek yaşama dönük kullanım alanlarına yönelik olarak orijinal metinlerle desteklenmesi gerekmektedir.

B... B.....

Vokallerin bazı kelimelerde yazılıp bazılarında yazılmaması öğrencinin kafasını karıştırmakta. Öğrencinin bununla ilgili kuralları edinip uygulamaya geçirmesi için ders saatlerinin yeterli olmadığı düşünülmektedir. Ders işleniş sürecinde öğretim elemanın tutumu, kuralları her firsatta sık sık tekrarlamak yerine, alışkanlıklar üzere kuralın bilindiğinin var sayılması şeklindedir. Kurallar kavratılana, yerleşene dek sık sık tekrarlanmalı, hatırlatılmalıdır.

En temel gerekçe, Arapça ve Farsça bilgisine sahip olmamak gibi görünüyor.

Kelimelerin Türkçeleşmiş hallerinde mevcut olan vokallerin orijinal dilde de mevcut olduğunu düşünmek. Örneğin Arapça طواف kelimesi yazılırken harfinden sonra açık bir vokal olmamasına rağmen kelimenin

F.... T...... Türkçeleşmiş halinde (Tavaf) bir vokal yer almaktadır. Bu durum da temel dil bilgisine sahip olmamakla bağlantlı elbette.

gibi Türkçede benzer sesler için kullanılan harflerin kullanım yerinin tam olarak öğrenilememiş olması.

Öğrencinin Arap alfabesine aşina olmamasından

i...... A....

Verilen kuralların istisnalarının olduğunu bilmemesinden

Harf ve ses ayrımının tam olarak yapılamaması.

Birleşen ve ayrı yazılması gereken harfler noktasında yeteri kadar uygulama yapılmaması.

Bugün dilimizde ses olarak yer alıp harf olarak yer almayan bazı seslerin öğrenciler tarafindan ayırt edilememesi.

Arapça ve Farsça kelimeler ile Türkçe kelimelerin bünyesinde yer alan ünlülerin hangilerinin yazılıp hangile-

H.... K.... rinin yazılmayacağı noktasında öğrencilerin yaşadığı sıkıntılar.

Yeteri kadar yazma çalışmaması yaptırılmaması.

Osmanlıca derslerinde Arapça unsurların gerektiğinden daha fazla üzerinde durulması, yazım ve okumanın bu sebeple yeteri kadar yaptrılmaması.

Yeteri kadar kelimenin tanınmaması.

Birleşmeyen harflerin birleştirilmesi.

Tablo: 6'da Öğretim Üyelerinin hataların sebepleri hakkındaki görüşleri yer almaktadır. Tablo incelendiğinde öğretim elemanlarının konuyla ilgili toplam 20 iteme (maddeye) işaret ettikleri, bunlardan birkaçına farklı öğretim elemanlarınca ortaklaşa dikkat çektikleri görülmektedir. Bunlar: (1) Transkript işaretlerini en başta öğretmeme ve sürekli kullanmama, (2) Türkçe kelimelerin imlası öğretilirken ünlülerin yazımı üzerinde aşırı durulması, (3) yeterince imla çaışmasının yapılmaması, (4) Arapça ve Farsça gramer bilgisinin yetersiz olması (2 kez), (5) öğrencilerin derse karşı gü- 
dülenmişlik düzeylerinin düşük olması, (6) vokallerin bazı kelimelerde yazılıp bazılarında yazılmaması, (7) kelimelerin Türkçeleşmiş hallerinde mevcut olan vokallerin orijinal dilde de mevcut olduğunun sanılması, (8) ders saatlerinin yeterli olmadığının düşünülmesi, (9) ders işleniş sürecinde öğretim elemanın tutumunun olması, (10) kuralların her firsatta sık sık tekrarlanmaması, (11) öğrencinin Arap alfabesine aşina olunmaması, (12) verilen kuralların istisnalarının olduğunun bilinmemesi, (13) ص ص / س vibi Türkçede benzer sesler için kullanılan harflerin kullanım yerinin tam olarak öğrenilememiş olmasıdır.

Tablo 7. Öğretim Üyelerinin Osmanlı Türkçesi dersinde öğrencilerin en çok zorlandıkları durumlarla baş edebilmeleri için yapttkları önerileri

\section{Soru}

Öğretim Elemanı

\section{7. Öğrencilerin karşılaştıkları zorluklarla baş edebilmeleri için neleri önerirsiniz?}

A..Y.....

M.... T....

B... B.....

F.... T.....

i............

H.... K....
Öğrenici ile iyi iletişim kurma, sıcaklık oluşturma.

Kelime yazımı konusunda mümkün olduğunca çok alıştırma yapılması gerekiyor.

Dersin gerçek yaşamdaki karşılığı bir ihtiyaç olarak hissettirilmeli, öğrenciler derse karşı güdülenmeli.

Vokallerin yazımıyla ilgili istisnai durumlar varsa bir liste hazırlanmalı, hazırlanan listenin ardından mutlaka örnek etkinlik uygulamalarına yer verilmeli. Hatta sadece vokal yazımıyla ilgili dersler yapılmalı.

Öğrenciyi sevme ve onu alıştırma yapmaya razı etme

Görsel hafizayı devreye sokmak gerekiyor. Öğrenci kelimeleri metin içerisinde ne kadar çok görürse o kadar aşina hale geliyor. Bu nedenle de metin okumaya teşvik edilmeli ve bunu yapmalarını zorunlu kılacak tedbirler geliştirilmeli.

Çokça metin okumalarını tavsiye ederim.

Bugün sahadaki birçok kitap dil bilgisi ağırlıklı. Derslerde Arapça ve Farsça unsurları verebilmek için yeteri kadar yazma ve okuma yaptıramıyoruz. Bilhassa okuma kısmı eksik kalınca öğrenci yeteri kadar kelime tanıyamıyor. Mutlaka Osmanlıcanın ders saati yükseltilmeli ve ileri düzey Osmanlıca için üçüncü sınıfta seçmeli bir ders olmalı.

Yazma için öğrenciler cesaretlendirilmeli.

Sınıflar çok kalabalık. Osmanlıca dersleri şubelere ayrılarak yapılmalı.

Öğrenciler her biri ayrı bir söz dünyasına sahip olan Milli Edebiyat, Servet-i Fünun, Tanzimat gibi dönemlere ait metinlerle daha çok muhatap oluyorlar. Dersi veren kişi Eski Türk Edebiyat hocası ise o da metinleri klasik edebiyat ağırlıklı seçiyor. Bunun yanında Halk Edebiyatında Dede Korkut, dil derslerinde Kutadgu Bilig gibi metinlerde Osmanlı Türkçesi öğrencilere daha zor geliyor. Zira bu metinlerdeki kelimeleri öğrenciler tanımıyorlar. Metin çeşitliliği sağlanırken dil, halk edebiyatı, eski edebiyat ve yeni edebiyat hocaları arasında maalesef koordinasyon yok.

Öğrenciler Osmanlıcayı öğrendiklerini zannedip her türlü kitabeyi, mezar taşını vs. okuyacağını düşünüyorlar. Ancak okuyamadıkları için hayal kırıklığı yaşıyorlar. Mutlaka farklı yazı çeşitlerine dair uygulamalar yaptırılmalı.

Tablo: 7. Öğretim elemanlarının Osmanlı Türkçesi dersinde öğrencilerin en çok zorlandıkları durumlarla baş edebilmeleri için yaptıkları önerileri yer almaktadır. Tablo incelendiğinde öğretim elemanlarının konuyla ilgili toplam 12 iteme (maddeye) işaret ettikleri, bunlardan birkaçına farklı öğretim elemanlarınca ortaklaşa dikkat çektikleri görülmektedir. Bunlar: (1) Öğrenici ile iyi iletişim kurma, (2) öğrenciyi sevme ve onu alıştırma yapmaya razı etme, (3) öğrenciler derse karşı güdüleme, (4) dersin gerçek yaşamdaki karşılı̆ıını bir ihtiyaç olarak hissettirme, (5) kelime yazımı konusunda mümkün olduğunca çok alıştırma yapma, (6) vokallerin yazımıyla ilgili istisnai durumlar için bir liste hazırlama, (7) sadece vokal yazımıyla ilgili dersler yapma, (8) metin okumaya teşvik etme ve bunu zorunlu kılacak tedbirler geliştirme (2 kez)dir. 
Tablo 8. Öğretim Üyelerinin Osmanlı Türkçesinin öğretimiyle ilgili faydalı olacağını düşündükleri önerileri

\section{Soru}

Öğretim Elemanı

A..Y.....

M.... T....

B... B....

F.... T.....

i............

H.... K....

\section{Osmanlı Türkçesinin öğretimiyle ilgili faydalı olacağını düşündüğünüz önerileriniz nelerdir?}

- En başta harfleri ve transkript işaretlerini öğretip öğrenicinin seveceği mısralardan başlayıp metne yönelme, bol bol alıştırma yaptırma. Emeksiz yemek olmaz.

Haftalık yazma ödevi verme

Sık sık alıştırma yaptırma

Çalışmaların ev ödevi şeklinde verilmesinin yanında sınıf içi işbirlikli uygulamalar yaptırılmalı. İstasyon tekniği gibi tekniklerden faydalanılarak grup çalışmaları desteklenmeli. Bu şekilde öğrencilerin dersin sıkıcı, kuralcı olduğu yönündeki eleştirilerine eğlendirerek öğretmeye uygun yöntem ve teknikleriyle cevap verilmelidir.

- Osmanlı Türkçesi tek döneme sıkıştırılan bir ders olmamalı. Örneğin ilköğretim Din Kültürü ve Ahlak Bilgisi Öğretmenliği bölümünde bu ders dördüncü sınıfin son döneminde verilmektedir. Bu son derece geçtir. Mezun olan öğrenciler henüz okuma aşamasındadırlar ve yazma yetenekleri henüz tam olarak gelişmiş değildir. İslami i̇limler Fakültesinde ise ders 1. sınıfta tek dönem okutulmaktadır. 1. sınıfta olması doğru, fakat tek döneme sıkıştııımış olması yanlıştır.

- Özellikle İslami illimler (ya da İlahiyat) fakültelerinde bu dersin öğretimi Arapça ile bir şekilde ilintilendirilebilirse başarı düzeyinin artacağı söylenebilir.

Her hafta yazım ödevi verme ve kontrol etme

Çokça metin okuma

Ders saati artırılmalı. Dersler şubelere bölünerek yapılmalı.

Yazma için daha fazla zaman ayrılmalı.

Osmanlıca ilk iki yıl öğretilip bırakılmamalı. Üçüncü sınıfta ileri düzey metin okumaları, eski yazı bilgisi gibi seçmeli dersler olmalı.

Dil, Halk Edebiyat, Eski Edebiyat ve Yeni Edebiyat hocaları arasında Osmanlı Türkçesi öğretiminde tam bir koordinasyon sağlanmalı.

Tablo: 8'de öğretim elemanlarının Osmanlı Türkçesinin öğretimiyle ilgili faydalı olacağını düşündükleri önerileri yer almaktadır. Tablo incelendiğinde öğretim elemanlarının konuyla ilgili toplam 8 iteme (maddeye) işaret ettikleri, bunlardan birkaçına farklı öğretim elemanlarınca ortaklaşa dikkat çektikleri görülmektedir. Bunlar: (1) Öncelikle harfleri ve transkript işaretlerini öğretme, (2) öğrenicinin seveceği mısralardan başlayıp metne yönelme, (3) bol bol alıştırma yaptırma (3 kez), (4) haftalık yazma ödevi verme (4 kez), (5) sınıf içi işbirlikli uygulamalar yaptırma, (6) istasyon tekniği gibi tekniklerden faydalanarak grup çalışmalarını destekleme, (7) Osmanlı Türkçesi dersinin tek döneme sıkıştıılan bir ders olmaması gerektiği, (8) Çokça metin okuma (3 kez)dır.

\section{Tartışma ve Yorum}

Elde edilen bulgular tahlil edildiğinde klasik Osmanlı Türkçesi'nin öğretilmesinde karşılaşılan sorunlarla ilgili olarak 4 ana noktanın öne çıktığı görülmektedir. Bunlar: okuma, yazma, gramer ve öğretim sürecidir. Bu 4 temel nokta çerçevesinde karşılaşılan zorluklar (hatalar) ele alınarak bunların sağaltılmaları için alan yazın kapsamında çareler önerilmiştir.

\section{Okuma hataları, sebepleri ve sağaltımaları}

Okuma ile ilgili karşılaşılan zorluklar: Arapça kelimelerinin kalıplarını, Osmanlıca metinleri okuyamama ile kelimelerin kökenini ayırt edememe, okuma ve yazmada kaf/kef/kâf-ı Farisi/ kâf-ı Türki sağır kef ayrımı yapamamaya bağı hatalardır.

Bu hataların sebepleri, kelimelerin anlamını bilememeye bağlı yanlış okuma, gramer kurallarını bilememeye bağı yanlış okuma, imla (yazım) bilgi eksikliğine bağlı yanlış okuma, Arapça kuralların içselleştirilmemesine, metinlerin çok az okunmasına ve alfabeyi oluşturan harflerin bitişik yazılırken biçimlerin değişmelerine bağlı olduğu söylenebilir.

Gramer kurallarını bilememeye bağlı yanlış okuma, imla (yazım) bilgi eksikliğine bağlı okuma hataları, grafik bakımdan benzer olan harflerin ayırt edilememesi öğrencilerin görme algılarındaki sınırlııkla açıklanabilir. Ayrıca okuma, yazma etkinliklerinin yeterince yapılmaması, okuma metinleri ile temaslarındaki yetersizlik de söz figürlerini tanıyamama

| Kastamonu Eğitim Dergisi, 27(4), 2019| 
ve ayırt edememe bakımından önemli bir etken olarak düşünülebilir.

Osmanlı Türkçesinin benimsediği Arapça Yazı sistemini (metni sağdan sola yazma) kavrayamamaya dayalı hatalara eklenebilir. Çalışkan $(2013,334)$, çalışmasında “...öğrencilerin bir kısmı anlamlandırabilme becerilerinin okuyabilme becerilerinden geride olduğunu" ifade etmişlerdir. Akpınar $(2016,10)$, çalışmasında "Bu başarısızlığın ardında 1. sınıfta sadece okuma öğrenen bireyin kelimelerin anlamına vâkıf olamaması yatmaktadır. Elbette Osmanlı Türkçesini bilmek yalnız alfabe meselesini çözmek değildir. Öğrenci okuduğuna anlam yükleyebilmeli ve özellikle Türkçe bölümündeki yeni Türk edebiyat, eski Türk edebiyatı derslerinde okutulan dönemin kelime hazinesini kavrayabilmelidir." görüşünü dile getirmektedir.

Yukarıda sıralanan hatalar, gerek öğretim elamanı gerekse öğrencilerin çaba ve gayretleri ile düzeltilebilir, asgariye indirilebilir.

\section{Yazma hata ve sağaltılmaları}

Yazma ile ilgili karşılaşılan zorluklar: Arapça ve Farsça kelimeleri, Arapça kelimelerinin kalıplarını, Osmanlıca metinleri yazamama ile ünlülerin yazımı ve Arap fonetiğine has harflerin yazımında zorlanma, yazımda kaf/kef/kâf-ı Farisi/ kâf-ı Türki sağır kef ayrımı yapamamaya bağlı hatalar şeklindedir.

Osmanlı Türkçesinde ünlülerin büyük bir kısmı yazılmakla birlikte eklerde ünlülerin yazılmaması, ince ve kalın karşılığı olan harflerden ince sesli harfle yazılması gereken kelime ve ekleri kalın sesli harfle; kalın sesli harfle yazılması

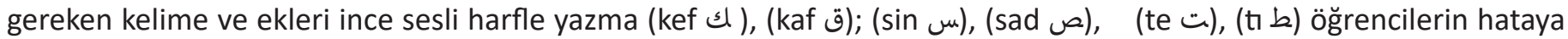
düşmesinde önemli bir etkendir.

Kef-kaf ayrımının yapılamaması, tek bir sembolün/harfin birden çok işleve sahip olması sebebine bağlı olabilir. Arap kökenli Türk alfabesinin kullanıldığı Türkçe metinlerde genellikle /g/ ile /k/ sesleri aynı harfle gösterilmektedir. Bu nedenle bu seslerde tonlu / tonsuz ayrımı yapılmamaktadır.

Bu konuda Develi "Osmanlı alfabesinde kef (ك) harfi birden fazla ünsüzü göstermek üzere kullanılmıştr. Bunlar, ince sıradan olmak üzere /k/, /g/, /ğ/ve hem kalın ünlülü hem de ince ünlülü kelimelerde damaksı /ñ/ ünsüzleridir. Başlangıçta /g/'yi /k/'den ayırmak için kimi metinlerde üç noktalı kef ve ya kâf-ı Farisi denilen bir harf ( ) kullanılmıştır. Sonraki dönemlerde bu işaret gitgide daha az kullanılmış, harfin /k/ ve ya /g/'den hangisini karşıladığının belirlenmesi cümlenin anlamına bağıı olarak okuyucuya bırakılmıştır." bilgisini vermektedir. (Develi, 2012, s. 65)

Öğrencilerden bazııının Osmanlı Türkçesinde yer alan Arapça kelimelerin yazımında duraksadıkları, hata yaptıkları, kelimelerdeki harflerin sırasını değiştirdikleri ya da kelimelerdeki harfleri farklılaştırdıkları gözlenmektedir. Bu durum Arapça kelimelerin yazımında önemli yer tutan kalıp/vezin bilgisinin içselleştirilemediğinin göstergesi kabul edilebilir.

Osmanlı Türkçesinde Türkçe kelimelerde konsonantların hepsi yazııır. Vokallerin ise bir kısmı yazılmaz. Türkçede uzun vokal yoktur. Hepsi kısa olan vokallerin umumiyetle büyük bir kısmı yazılır, fakat bir kısmı da yazılmaz. Bunun kesin bir ölçüsü olmadığı gibi eski ve yeni devirler arasında da bu bakımdan birçok farklar vardır. Umumiyetle eski yazıda, fakat bilhassa vokallerin yazılıp yazılmaması bakımından Türkçenin hiçbir zaman kesin ve sağlam bir imlâsı olmamıştır.

Öğrencilerden bazısının Osmanlı Türkçesinde genel olarak kabul edilmiş "eklerde ünlü kullanmama” kuralına uymadıkları, kelime kök ve gövdelerine getirilen ekleri Türkiye Türkçesinin benimsediği "her hecede hece doruğu oluşturan bir ünlünün bulunması" durumuna uygun yazma eğiliminde oldukları görülmektedir.

Calp, (2017) yılında yaptığı çalışmasında, Osmanlı Türkçesi Dersindeki Yazma Hataları başlıklı çalışmasında "çalışma grubunu oluşturan öğrencilerin yaptıkları yazım yanlışlarının büyük ölçüde kelimelerin grafik yapısını tanıyamamaya bağlı yazım hataları olduğu, öğrencilerin en fazla yaptığı yazma hatalarının gramer bilgi eksikliğine bağı yazma hataları; sağır kef ile yazııması gereken kelime, ek ve harfleri (ağızsı $n$ ) ile yazma; fonetik ayrım yapamamaya bağlı yanlış yazma; kelime kök, gövde ve eklerin birleşiminde ince ve kalın harf ayırımı yapamama; kelimeleri oluşturan harflerin sırasında değişiklik yapma; kelimelerin yazımında gereksiz harf üretme; Türkçe kelime köklerine gelen ekleri yanlış yazma; ince ve kalın karşıı̆ı olan harflerden ince sesli harfle yazılması gereken kelimeleri kalın sesli harfle; kalın sesli harfle yazılması gereken kelimeleri ince sesli harfle yazma; bağlı yanlış yazma olduğunu belirtmektedir.

\section{Gramer hata ve sağaltılmaları}

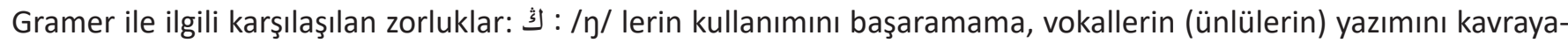
mama, Arapça kelimelerin kalıplarının anlama ve işleve olan katkısını kavrayamama, ince ve kalın harflerin kullanımını (kaf ile kef, sad ile sin, tyy ile te ...) ayırt edememe, fonetik ayrım yapamama, bitişen ve bitişmeyen harfleri ayırt edeme- 
me, Arap fonetiğine has harflerin yazımı, kelimelerin Türkçe mi, Arapça mı yoksa Farsça mı olduğunu kavrayamamaya bağıı hatalar şeklindedir.

Çalışkan $(2013,334)$, çalışmasında "öğrencilerin belli dil değişkeleri ve türlere ait metinlere aşina olmaması; dolayısıyla bu metinlerin kendine özgü dil yapısını çözümleyememeleri etkili olmaktadır. Bu da Osmanlı Türkçesi öğretiminin basit bir alfabe ve yazı sistemi öğretiminin ötesinde belli bir dönemin ya da belli dil değişkeleri ve türlerin dili olarak da ele alınması gerektiği”ni belirtmektedir.

\section{4. Öğretim süreci hata ve sağaltılmaları}

Öğretim süreci ile ilgili karşılaşılan zorluklar: Osmanlı Türkçesi dersi için ilk sınıfta yeteri bilgi ve beceri elde edememe, derse yeterli zaman ayırmama, düzenli ders çalışma alışkanlığına sahip olmama, ön bilgiye sahip olmama, ders çalışma (ödev/alıştırma yapma)ya karşı isteksizlik, öğreticilik bakımında öğretimin yeterli olmaması şeklindedir. Bunlar aynı zamanda başarısızlığın sebepleri durumundadır.

Öğretim görevlileri öğrencilerin dersin zorluğu ile ilgili taşıdıkları endişe yanında motivasyon eksikliği ile karşılaşmaktadır. Türkçe Eğitimi bölümündeki öğrencilerin Osmanlı Türkçesini hayatlarının bir yerlerine yerleştirememeleri ya da meslek yaşantılarına taşıyamayacakları endişesi, Çalışkan'ın araştırmasına göre Sosyal Bilimler Lisesi öğrencileri için de geçerlidir (Çalışkan, 2013).

Başarısızlığın sebeplerinden biri olan "ders çalışma (ödev/alıştırma yapma)ya karşı isteksizlik" karşısında Akpınar $(2016,10)$, çalışmasında "Öğrencilere, Osmanlı Türkçesi bilmenin onlara sağlayacağı faydalar anlatılmalıdır. Sahip olacakları ayrıcalıkla birlikte tarihî, edebî eserleri ilk elden okuma zevkine erişecekleri, dilin tüm inceliklerini kavrayacakları, güzel ve etkili bir Türkçe ile konuşabilecekleri anlatlırken; Türkçe öğretmeni olarak, dilin bir dönemi olan Osmanlı Türkçesini bilmeleri gerekliliği üzerinde durulmalıdır." görüşünü ileri sürmektedir.

Osmanlı Türkçesi derslerinin öğretiminde karşılaşılan sıkıntılardan biri de ders kitaplarının niteliğidir. Baskı kalitesi düşük kitaplar öğrencilerin okuma isteğini düşürmektedir. Akpınar $(2016,11)$, çalışmasında "Bu sebeplerle artık dijital ders kitaplarına geçilerek, öğrencilere daha sağlıklı metinler sunulmalı, ayrıca çağın da gerektirdiği gibi öğretim görevlisi bilgisayarına metinler indirip çıkt alabilmelidir." görüşünü ileri sürmektedir. Son yıllarda pedogojik özellik taşıyan ders kitaplarının yayınlanmaya başlanması olumlu bir gelişmedir.

Dersin haftalık saati yetersizdir denebilir, ders saatinin yetersizliği müfredatın kavuşmamasına yol açmaktadır. Bu konuda, Çalışkan (2013), araştırmasında “...öğrencilere Osmanlı Türkçesi dersine ayrılan süreyi hem öğretim yılı hem de haftalık ders saati açısından yeterli bulup bulmadıklarını sormuştur. Görüşmeye katılan öğrencilerin önemli bir kısmının ders saatini yetersiz bulduklarını, ...ders saatinin arttırılması gerektiğini istediklerini" belirtmiştir. Akpınar $(2016,9)$, "Öğrenme sürecinde yazmayı öğrenmedikçe, alfabeyi okumanın yeterli olamayacağı bilindiğine göre, müfredat genişletilirken, ders saatinin de arttrılması yoluna gidilmelidir." görüşündedir.

Osmanlı Türkçesi öğretiminde karşılaşılan olumsuz etkenlerden biri de dersle ilgili bir "zorluk" algısının olmasıdır. Öğrencilerdeki bu önyargının sebebi, yeni bir ortama gelmenin de verdiği tedirginlikle sanki daha önce hiç duymadığı, okumadığı bir dille karşılaşacağını sanmalarıdır.

Tespit edilen önemli sorunlardan biri de öğretim sürecinde izlenen yöntem ve materyal olarak kullanılan kitaplardır. Aynı veya farklı üniversitelerde, öğretim elamanlarının farklı kitaplarla dersleri işlemesi öğrenme sürecinde bir uyum problemi oluşturmaktadır. Ders kitapları hazırlanırken, öğrencilerin tek başlarına kavrayabilecekleri nitelikte alıştırmalara yer verilmesine dikkat edilmesi, başarıyı arttıracaktır.

\section{Sonuç}

Osmanlı Türkçesi dersi bir bilgi edinme alanı olmakla birlikte daha çok bir beceri alanıdır. Osmanlı Türkçesinin doğru, güzel, açık ve anlaşııır okunup yazılabilmesi yoğun çaba harcanmasına bağlıdır. Kas ve beyin gücünün eşgüdümüne dayalı bu alanda tekrar ve alıştırmaların önemli bir yeri vardır. Kazandırılacak doğru beceri ve alışkanlıkların öğrencilerde yer edip etmediğinin zaman zaman kontrol edilmesi ve rehberlikte bulunulması önemlidir.

Osmanlı Türkçesinin bünyesinde bulunan Türkçe Arapça ve Farsçanın kendilerine has yapısı bulunmaktadır. Farklı dilbilimsel yapıya sahip bu üç dilin Osmanlı Türkçesine yansıyan özellikleri de doğal olarak farklıdır. Türkçe büyük ölçüde fonetik bir dil olduğu halde Arapça, Farsça tamamen farklıdır. Özellikle bükünlü bir dil olan Arapçanın fonetik yapısı öğrencilerin Arapça kelimeleri tanımada bir takım güçlükleri beraberinde getirmektedir.

Arapçanın bir tek yuvarlak ünlüsüne (vav $9 / \mathrm{u} /$ ve /ü/) karşılık Türkçede dört yuvarlak ünlü vardır: /o/, /ü/, /u/, /ö/.

| Kastamonu Eğitim Dergisi, 27(4), 2019| 
Bu ünlüleri ayırt etmek için Osmanlı alfabesinde özel bir işaret kullanılmamıştır. Dört ünlünün de aynı harfle yazılması,

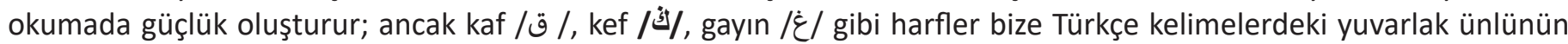
kalın veya ince sıradan olduğunu belirlemede yardımcı olabilir. Kelime başında te / de bu ayrımda yardımcı olur. Yine de kelimenin dar veya geniş olup olmadığını belirlemek alfabeden mümkün olmaz. Mesela وق hecesi ku - ko; hecesi kü - kö veya gü - gö şeklinde okunabilir.

Bu gibi kalın ve ince sıradan karşıtları bulunan harfler dışında yuvarlak ünlünün niteliğini tespit etmek için cümledeki anlamdan ve genel kültürel donanımdan başka bir yardımcı yoktur (Develi, 2012). Bütün bu durumlar, öğrencilerin aynı fakat farklı işlevlere sahip sembol/harflerle yazılan kelimeleri okumakta zorluk çekmektedirler. Harflerin birleşmelerindeki özel durumların kelimelerin okunamamasında etkili olduğu söylenebilir. Birleşik harf kombinezonları metnin algılanmasını zorlaştııcı bir faktör olarak düşünülebilir.

\section{6. Öneriler}

\section{Elde edilen bulgulardan hareketle aşağıdakiler önerilmiştir:}

Dil eğitiminin okuma, dinleme, anlama, anlatma ve yazma gibi alanlarında bilgi kazandırmaktan daha çok, beceri edindirmeyi gerektirir. Beceriler ise, ancak yaparak yaşayarak öğrenilir. Bu bakımdan yazı öğretimine tabi tutulan öğrencilerin bol bol yazı alıştırması yapmaları yerinde olur. Ancak, Yazma etkinlikleri, öğrencileri bıktırıp usandıracak ve olumsuz tutum geliştirecek ölçüye vardırmamalıdır.

Öğrenciler; düzgün, okunaklı, temiz ve seri yazma becerisi kazanmalılar. Bu becerilerin kazanılmasının titiz ve uzun süreli çalışma sonucunda gerçekleşebileceği unutulmamalıdır. Yazı öğretiminde öğrencide güzel yazma isteği uyandırmak önemlidir. Yazma etkinlikleri Osmanlı Türkçesi dersiyle sınırlı kalmamalıdır.

Okuma öğretimi ile yazı öğretimi arasında organik bir bağ kurulmalıdır. Okuma ve yazma etkinliği her zaman birlikte yürütülmeli; öğrencilere okumasını öğrendikleri cümle ve kelimeler aynı zamanda yazdııılmalıdır. Her okuma, yazmayı; her yazma da okumayı izlemelidir.

Osmanlı Türkçesi dersinde, yazma çalışmalarında öğrencilere hazırlık yapmadan yazı yazdırılmamalıdır. Kelimelerin anlamları metinlerden hareketle kavratılmalıdır.

Bir harfin, kelimenin veya metnin aynı sayfa üzerinde ve aynı zaman dilimi içerisinde defalarca yazdırımamasıdır. Bunun yerine öğretmen veya bir yetişkinin kontrolünde yeteri kadar sık aralıklarla az ve öz çalışma yapmak daha yararııdır. Yazmayı öğrenme aşamasındaki yanlışlar, anında düzeltilmelidir. Yanlış bir yazım anında düzeltilmez ise, bu durum alışkanlık haline gelir.

Yazı öğretiminde açık, tutarlı ve öğrencinin problemine dönük geri bildirimler vermek veya açıklamalar yapmak en az doğruyu göstermek kadar etkilidir.

Osmanlı Türkçesinin iki ders saatiyle sınırlı olması ve sınıfların kalabalık oluşu öğretimi olumsuz yönde etkilemektedir. Yazma etkinlikleri Osmanlı Türkçesi ders saatiyle sınırı kalmamalıdır. Sınıfların azami 30 kişi ile sınırlı tutulması yerinde olur. Özellikle yazı çalışması yaptırıırken, öğrencilerin kalem hareketlerini kontrol edebilmek, ödevlerini gözden geçirmek ve hataları düzeltebilmek için sınıfların makul sayıda öğrenci ile ders işlenmesi sağlanmalıdır.

Yazı eğitimi sırasında kullanılacak yazı malzemelerinin niteliği kadar, öğretmenin tahtaya yazı örneklerini yazarken kullanacağı harflerin büyüklüklerine dikkat etmesi de önemlidir.

Öğrenciler, ilk kez yeni bir yazı sistemi ile karşılaştıkları için huzursuzluk ve tedirginliğini yaşarlar. Bu endişe ve kaygılarını dindirmek öğretmen için en önemli amaç olmalıdır. Osmanlı Türkçesi ile ilgili çeşitli olumsuz ön yargılara sahip öğrencilere rehberlik edilmelidir. Bunun için öğretmenler öğrencilerin psikolojik ve sosyal özelliklerini iyi bilmelidir. Öğrencilerin bu özelliklerini bilen, uygun yöntem ve teknikleri yerinde ve zamanında işe koşan öğretmen olumlu gelişmelerin yolunu açabilir.

Öğretim elemanlarının Osmanlı Türkçesi dersini okuturken ilk başarmaları gereken şeyin öğrencilerin dikkatini, ilgisini çekmek, onları derse karşı heveslendirmek olduğu bilinmelidir. Bunun için, başlangıçta aşina oldukları hikâye, şiir, atalar sözü ve fikra gibi kısa, kolay ve tanıdık metinlerin seçilmesi önemlidir. Öğrencilerin dikkatleri yakın çevrelerindeki mezar taşlarına, tarihî yapılara; cami, müze ve kütüphanelerdeki Osmanlı Türkçesiyle yazılan eserlere çekilmelidir.

Dil becerileri bol alıştırma ve uygulamalar ile kazandırılabilir. Alışkanlık ve becerilerin elde edilmesinde ise öğrenici durumunda bulunan varlık, birinci derecede rol oynar. Bu sebeple ana dili eğitim ve öğretiminde öğrenci merkeze alınmalıdır. Öğrenci ne kadar çok etkinliğe katılırsa, dil becerileri alanında o kadar başarı sağlanır. Uygulama aşamasında 
yoğun etkinliklerle tekrar ve alıştırmalar yapılmalıdır.

Öğrencilerin ders kitapları dışında da Osmanlı Türkçesi metinlerini okumaları ve bunları sınıf ortamında arkadaşlarıyla paylaşmaları sağlanmalıdır.

Osmanlı Türkçesi dersinin temelini teşkil eden dil bilgisi öğretiminde öğrencilere kural ezberletmekten kaçınılmalı; Türk dilinin incelikleri ve zevki sezdirilerek kazandırılmalıdır. Dil bilgisi konuları okuma ve yazma etkinlikleri ile eş zamanlı işlenmelidir.

Dönem başında Osmanlı Türkçesi ile hat, tezhip minyatür gibi sanat eserleriyle öğrencilerin yüzleştirilmesi imrendirici olacaktr.

Kazandırılacak doğru beceri ve alışkanlıkların öğrencilerde yer edip etmediğini zaman zaman kontrol etmek ve rehberlikte bulunmak gerekir.

Yazı öğretiminde açık, tutarlı ve öğrencinin problemine dönük geri bildirimler vermek veya açıklamalar yapmak en az doğruyu göstermek kadar etkili olabilmektedir.

Bir diğer konu ise dersin ölçme ve değerlendirmesidir. Ders içeriğinin genellikle okuma üzerine odaklanması, sınavlarda "yazma ve gramer" alanlarının ölçülmesinin ihmaline yol açabilir. Ölçme ve değerlendirmenin geçerli ve kapsayıcı olmasına özen gösterilmelidir.

\section{Teşekkür}

Görüşlerini bizimle paylaşarak bu çalışmanın gerçekleştirilmesine katkıda bulunan değerli hocalarıma teşekkür ve saygılarımı sunarım.

- Öğretim Üyesi Fatih Taştan Ağrı İbrahim Çeçen Üniversitesi ilahiyat Fakültesi.

- Öğretim Üyesi Mehmet Terzi Artvin Çoruh Üniversitesi'nin Türk Dili ve Edebiyatı Bölümü Bölüm Başkanı

- Öğretim Üyesi Bora Bayram Bayburt Üniversitesi, Eğitim Fakültesi, Türkçe Eğitimi ABD,

- Öğretim Üyesi Ibrahim AKYOL ÇAKÜ, Çankırı Karatekin Üniversitesi Edebiyat Fakültesi

- Öğretim Üyesi Hasan Kaplan - Hatay Mustafa Kemal Üniversitesi (H. Kaplan hocam dergi süreci başladıktan sonra görüşlerini ilettiler.)

- Öğretim Üyesi Ali Yetmiş hocamızın görev yerini belirleyemedim; kendilerinden özür diliyorum

\section{Kaynakça}

Akpınar, Ş. (2016). Osmanlı Türkçesi Öğretimi Üzerine, Uluslararası Sosyal Araştırmalar Dergisi, Cilt: 9 Sayı: 44.

Calp, M. (2017). Türk Dili ve Edebiyat Bölümü 2. Sınıf Öğrencilerinin Osmanlı Türkçesindeki Yazma Hataları, Türk ve İslam Dünyası Sosyal Araştrmalar Dergisi, Yıl: 4, Sayı: 11, Haziran 2017, s. $28-53$.

Canpolat, M. (1981). "Arap Yazııı Türk Alfabesinin Gelişmesi”, Harf Devriminin 50. Yılı Sempozyumu, TTK Yayıncılık, Ankara.

Çalışkan, N. (2013). Lise Düzeyindeki Osmanlı Türkçesi Dersi Öğretim Programı́nın Uygulanışına İlişkin Öğrenci Görüşlerine Dayalı Bir Değerlendirme, Bartın Üniversitesi Eğitim Fakültesi Dergisi, Cilt: 2, Sayı: 2.

Develi, H. (2012). Osmanlı Türkçesi Kılavuzu I, İstanbul: Kesit Yayınları, Dil - Gramer.

Ertem, R. (1991). Elifbe'den Alfabe'ye, Dergâh Yayınları, İstanbul-1991.

Karasar, N. (2003). Bilimsel Araştırma Yöntemi, Ankara: Nobel Yayın Dağıtım Ankara.

Korkmaz, Z. (1995). Türk Dili Üzerine Araşttrmalar, T.D.K. Yayınları, Ankara-1995.

MEB. (2011). Sosyal Bilimler Lisesi Osmanlı Türkçesi Dersi (10, 11 ve 12. sınıflar) Öğretim Programı. http://ttkb.meb.gov.tr/program2.aspx?islem $=1 \& \mathrm{kno}=170$ adresinden 21.02.2018 tarihinde alınmıştir.

Özkan, M. (2011), Eski Anadolu Türkçesi Döneminde Ortaya Konan Tercümelerin Türk Diline Etkisi, Dil ve Edebiyat Araştırmaları Dergisi, S.3, Kı̧̧. Özkan, M., Osmanlıca (bk. Osmanlı Türkçesi). http://www.islamansiklopedisi.info/dia/pdf/c33/c330301.pdf (Son Erişim Tarihi: 05.09.2017) Polat, Nazım H. (2000) İctihad, http://www.islamansiklopedisi.info/dia/pdf/c33/c330301.pdf

Sevim, O., Bayındır, H. (2016). Lise ve üniversite öğrencilerinin Osmanlı Türkçesi dersine yönelik görüşlerinin incelenmesi. Ekev Akademi Dergisi, 20(67): 291-302.

Timurtaş, F, K. (1995). Osmanlı Türkçesi Grameri III, i̇stanbul: Alfa Basım Yayım Dağıtım.

Ülkütaşır, M. (1991), Şakir, Atatürk ve Harf Devrimi, Atatürk Kültür, Dil ve Tarih Yüksek Kurumu Türk Dil Kurumu yayınları: 384, 2. Baskı, Ankara.

Üst, S. (2008) Turkish Studies, International Periodical For the Languages, Literature and History of Turkish or Turkic Volume 3/6 Fall 2008.

Yuldırım, A. ve Simșek, H. (2011). Sosyal bilimlerde nitel araștirma yöntemleri. (8. Baskı). Ankara: Seçkin Yayıncluk.

| Kastamonu Eğitim Dergisi, 27(4), 2019| 


\section{EK: 1,2}

\section{Saygıdeğer meslektaşım,}

Osmanlı Türkçesi dersinde öğrencilerimizin “yaptığı hataların sebepleri, bu hatalarla baş edebilmenin çareleri” hakkında bilimsel bir araştırmaya veri elde etmek üzere hazırlanan yapılandırılmış bu görüşme formunda 4 soru bulunmaktadır. Bu soruları, lütfen anketin altındaki boşluğa soru numarasını belirterek cevaplayınız. Cevaplarınız, yaklaşık 5-6 dakikanızı alacaktır.

Katkılarınız ve yardımlarınız için teşekkür eder, çalışmalarınızda kolaylıklar dilerim. Saygılarımla... (Mehrali CALP)

Bulgular

1. Kelime bünyesinde bitişik yazılması gereken hece, ses/harf (fonem) ve sesbirimcik (morfem) gibi gramatikal unsurları ayrık yazma

- Arapça (nehar) sözcüğünü (ne-har نحلر ) şeklinde ayrık yazma

- Arapça (tavaf) تاواف (ile) (تاون (şeklinde yazma

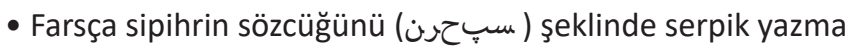

- Türkçe (döne دونه) kelimesinde bitişik yazılması gereken harfleri (دون0) ayrık yazma

2. Kelimenin yapısında ayrık yazılması gereken dil birimlerini (kelime, hece, ek, harf) bitişik yazma

- Türkçe (eylemezlerdi اليلهمزلردى) kelimesinde kendinden sonra gelen harflerle bitişmeyen (zıy j) harflini lam ile bitişik yazma

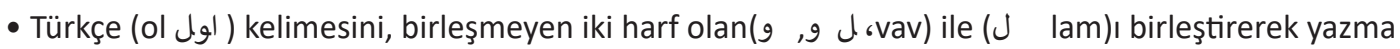

- Türkçe (yandı يانى ) ve (eylemezlerdi اليلمزلمى) kelimelerinde bulunan (-di 1 ) ekindeki dal د ile y ى 'yi bitişik yazma

3. Kelimenin yapısında bulunan harflerin sırasında değişiklik yapma

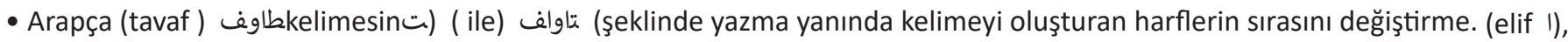
(vav g)'dan sonra yazılması gerekirken (vav g)dan önce yazma

4. Kelimelerin yazımında gereksiz harf üretme

- Türkçe (beni بنى) kelimesinde gereksiz olarak (e o) harfi kullanma.

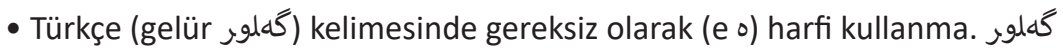

5. Türkçe kelime köklerine gelen ekleri yanlış yazma

- Türkçe (-den دن) ayrılma hal ekini (-gân كآن şeklinde yazma (033 F. T.)

- Türkçe (olmasa اولماسا ) kelimesindeki dilek-şart kipini (sad ص) ile (اولماصا) şeklinde yazma

6. Sağır kef ile yazılması gereken kelime, ek ve harfleri (ağızsı n) ile yazma

- Arapça ('aşkun عشقوكث ) kelimesine eklenen genetiv ekini (sağır kef) ile yazma yerine (nun ) ن'la yazma

- Türkçe (donuz طوكوز) kelimesini (dokuz دوقوز ) şeklinde yazma (010 T. Adıgüzel)

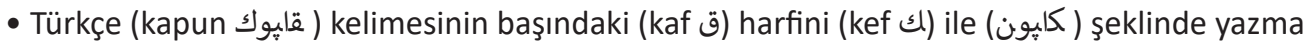

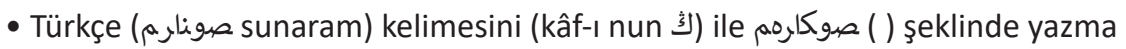

7. Yazımı biçim bakımından benzer olan harfleri değiş tokuş etme (y( ,), ىn( , ن)t( ; ت)cim( , ج)ha( ; ح)gayın), غ̇(ayın( , ع )fe(

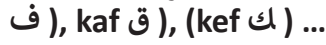

- Türkçe (ne نه ) soru edatını ى ile (ye يه ) şeklinde yazma (013 E. Ş.)

8. Ince ve kalın karşılığı olan harflerden ince sesli harfle yazılması gereken kelime ve ekleri kalın sesli harfle; kalın sesli harfle

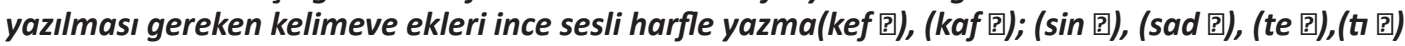

- Arapça (Kâbe كابه) kelimesini (kaye قايه ) şeklinde yazma

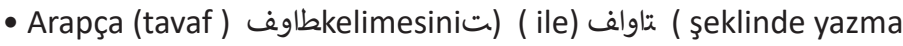

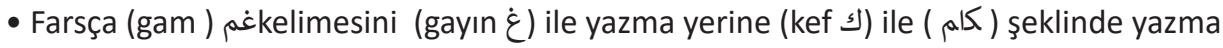

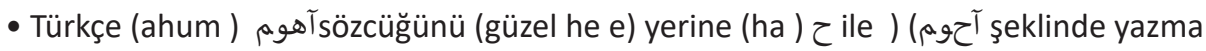

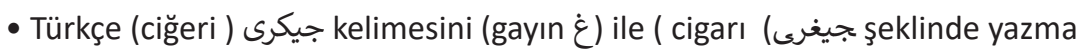

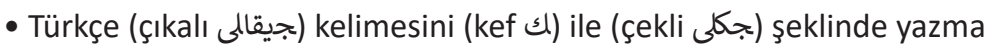

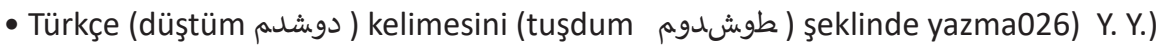

- Türkçe (geldiğini كلديكينى) kelimesini kaf ile (kaldiğini قلديكينى) şeklinde yazma

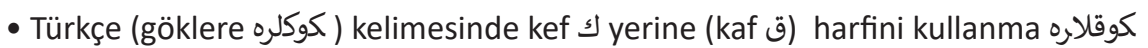

- Türkçe (kıldı قيلدى) kelimesindeki (kaf)ı (kef (كيلطي) şeklinde yazma

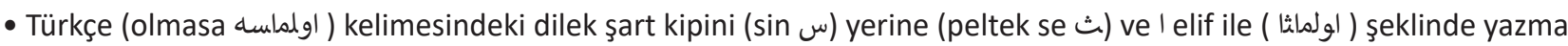




\section{Dilbilgisi bilgi eksikliğine bağlı yazma hatası yapma}

- Arapça ('aşkun عشقوكث ) kelimesini genetiv eki yerine ( ن nun)'la yazma

- Farsça (zülf-ı siyeh-kâre) tamlamasında tamlanan ünsüzle bitmesi karşısında izafet kesresi yerine (ya $、$ ) kullanma

- Türkçe (-den

- Türkçe (düştüm دوشدم) kelimesindeki görülen geçmiş zaman ekini t ile دوششطومن şeklinde yazma

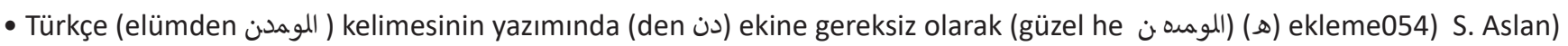

- Türkçe genetiv hal ekini (sağır kef ŝ́) yerine (nun ) نla yazma

- Türkçe (kapun قايوك) kelimesindeki genetiv hal ekinde (sağır kâf) yerine (nun ن) harfini kullanma

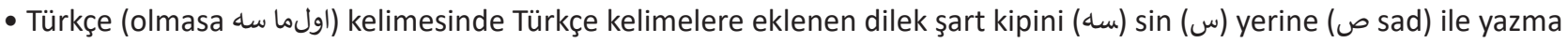

• ।. Türkçe kelimelerde bağlant ünlüsü kullanılması gereken durumlarda ünlü kullanmama; bağlantı ünlüsü kullanılmaması gereken durumlarda ünlü kullanma

- Türkçe (beni بنى) kelimesini gereksiz harf ekleyerek (bani ) بـ şeklinde yazma

- Türkçe (gelür كلور) şeklinde yazılması gereken kelimeyi (kâlur كابنور) şeklinde yazma

11. Uzun ünlü kullanılmaması gereken Arapça kelimelerde uzun ünlü kullanma; uzun ünlü kullanılması gereken durumlarda uzun ünlü kullanmama

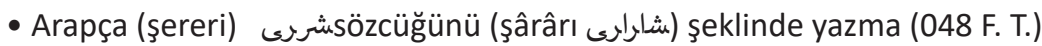

- Arapça (tavaf طواف ) kelimesinde gereksiz (elif I) kullanarak طواواف şeklinde yazma (064 M. D.)

\section{Fonetik ayrım yapamama}

- Arapça ('aşkun عشقوك) kelimelerindeki kaf harfini (kef) ile (عشكون ) şeklinde yazma

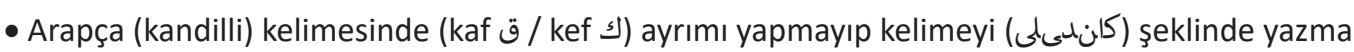

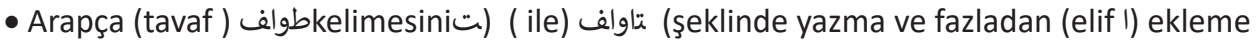

- Türkçe (çıkalı جيقالى) kelimesini (çekli جكلى) şeklinde kef ile yazma

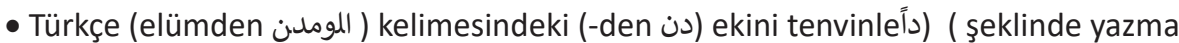

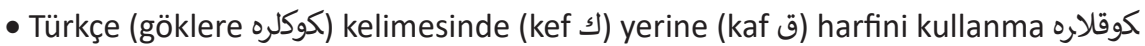

• Türkçe (kalup ) قالموكي kelimesini (kâlup şeklinde yazma

13. Osmanlı Türkçesinin benimsediği / kullandığı Arapça Yazı sistemini kavrayamamaya dayalı hata (Osmanlıca metni sağdan sola yazma)

- Birinci mısrayı Osmanlıcaya çevirmeye doğru başlayıp sonraki mısrada tersten devam etme. (059 AA)

- Kelime içindeki harflerin birleşik ya da ayrı yazımında gelişigüzel hareket etme

\section{Imla/Yazım yanlışı yapma}

- Arapça ('aşkun عشقوك) kelimesini (kaf) yerine (kef) ile yazma; عشكون

- Arapça (gark غرق sözcüğü kark قارق şeklinde yazma

- Arapça (sevda سودا kelimesinin bünyesindeki (dal)ı (t ط طوقطا ) ile ) şeklinde yazma

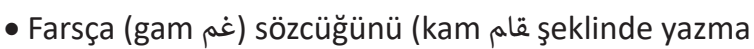

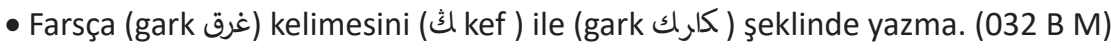

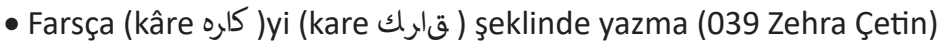

- Türkçe (جcıkalı جاقاقلى ) kelimesini (cakalı ) şeklinde yazma

•Türkçe (düştüm دوشدم) kelimesindeki (dal)'ları kendinden sonra gelen vav'la bitişik yazma دوشدوم

Sorular

1. Örnekleri gösterilen hata/ların niçin yapıldığını düşünüyorsunuz?

2. Osmanlı Türkçesi dersinde öğrencilerimizin en çok zorlandığı husus/lar nelerdir?

3. Öğrencilerin karşılaştkkları zorluklarla baş edebilmeleri için neleri önerirsiniz?

4. Osmanlı Türkçesinin öğretimiyle ilgili faydalı olacağını düşündüğünüz önerileriniz nelerdir? 